Article

\title{
A Study of the Mechanism and Separation of Structurally Similar Phenolic Acids by Commercial Polymeric Ultrafiltration Membranes
}

\author{
Qinshi Wang ${ }^{1,2}$, Yun Zhang ${ }^{1,2}$, Xianli Zhang ${ }^{1,2}$, Qi Li ${ }^{1,2}$, Mingcong Huang ${ }^{1,2}$, Shasha Huang ${ }^{1,3}$, Qianlian Wu ${ }^{1,2}$ \\ Zhishu Tang ${ }^{4}$, Linmei Pan ${ }^{1,2}$, Yue Zhang ${ }^{1,2}$, Hongbo Liu ${ }^{4}\left(\mathbb{D}\right.$, Bo Li $^{1,2,5, *}$ and Huaxu Zhu 1,2,* \\ 1 Jiangsu Collaborative Innovation Center of Chinese Medicinal Resources Industrialization, Nanjing \\ University of Chinese Medicine, Nanjing 210023, China; 15850600541@163.com (Q.W.); \\ zycloud1016@163.com (Y.Z.); zhangxli2022@163.com (X.Z.); 1q23400@163.com (Q.L.); \\ wongmingcong@163.com (M.H.); ssh_1126@126.com (S.H.); wq1961114@163.com (Q.W.); \\ linmeip@126.com (L.P.); zhyue@njucm.edu.cn (Y.Z.) \\ 2 Jiangsu Research Center of Botanical Medicine Refinement Engineering, Nanjing University of Chinese \\ Medicine, Nanjing 210023, China \\ 3 Simcere Pharmaceutical Co., Ltd., Nanjing 210042, China \\ 4 Shaanxi Collaborative Innovation Center of Chinese Medicinal Resources Industrialization, Shaanxi \\ University of Chinese Medicine, Xianyang 712046, China; tzs6565@163.com (Z.T.); \\ 15319084280@126.com (H.L.) \\ 5 The First Clinical Medical College, Nanjing University of Chinese Medicine, Nanjing 210023, China \\ * Correspondence: boli@njucm.edu.com (B.L.); zhuhx@njucm.edu.cn (H.Z.)
}

\section{check for} updates

Citation: Wang, Q.; Zhang, Y.; Zhang, X.; Li, Q.; Huang, M.; Huang, S.; Wu, Q.; Tang, Z.; Pan, L.; Zhang, Y.; et al. A Study of the Mechanism and Separation of Structurally Similar Phenolic Acids by Commercial

Polymeric Ultrafiltration Membranes. Membranes 2022, 12, 285. https://doi.org/10.3390/ membranes12030285

Academic Editor: Isabel C. Escobar

Received: 14 January 2022

Accepted: 25 February 2022

Published: 1 March 2022

Publisher's Note: MDPI stays neutral with regard to jurisdictional claims in published maps and institutional affiliations.

Copyright: (c) 2022 by the authors. Licensee MDPI, Basel, Switzerland. This article is an open access article distributed under the terms and conditions of the Creative Commons Attribution (CC BY) license (https:// creativecommons.org/licenses/by/ $4.0 /)$.

\begin{abstract}
This study examined the behavior and penetration mechanisms of typical phenolic (benzoic) acids, which determine their observed penetration rates during membrane separation, focusing on the influence of electrostatic and hydrophobic solute/membrane interactions. To understand the effects of hydrophobicity and electrostatic interaction on membrane filtration, the observed penetration of five structurally similar phenolic acids was compared with regenerated cellulose (RC) and polyamide (PA) membranes at different solute concentrations and solution pHs. Variation partitioning analysis (VPA) was performed to calculate the relative contributions of electrostatic and hydrophobic effects. The penetration of phenolic acids was mainly influenced by the electrostatic interaction, with salicylic acid having the highest penetration. Penetration of phenolic acids through the PA membrane decreased from $98 \%$ at $\mathrm{pH} 3.0$ to $30-50 \%$ at $\mathrm{pH} 7.4$, indicating the dominance of the electrostatic interaction. Moreover, based on its hydrophobicity and greater surface charge, the PA membrane could separate binary mixtures of protocatechuic/salicylic acid and 4-hydroxybenzoic/salicylic acid at $\mathrm{pH}$ 9.0, with separation factors of 1.81 and 1.78, respectively. These results provide a greater understanding of solute/membrane interactions and their effect on the penetration of phenolic acids through polymeric ultrafiltration membranes.
\end{abstract}

Keywords: adsorption; penetration mechanism; phenolic acid compounds; LogD; charge

\section{Introduction}

Phenolic acids, common secondary metabolites of plants, are found widely in vegetables (e.g., artichokes, olives, and maize), fruits (e.g., grapes, apples, pears, cherries, and berries), beverages, cereals, and other foods [1]. Phenolic acids constitute an important source of bioactive compounds in the human diet because of their wide distribution in plants [2]. In addition, phenolic acids are essential active components of traditional Chinese medicines (TCM) and are found in over 100 TCMs, including Pinellia ternata, Salvia miltiorrhiza Bunge, and Paeonia lactiflora Pallas [3]. Furthermore, the anti-inflammatory [4,5], anticancer [6], antibacterial [7], anti-oxidation, and anti-oxidant [8] activities of phenolic acids are widely used in medical, food, and personal care products. For example, salicylic acid (SA) is the starting material for some synthetic drugs $[9,10]$, such as aspirin and 
glyburide, and also a raw material or synthetic intermediate for food preservatives [11], dyes [12], and pesticides [13]. The anti-oxidant, anti-inflammatory, and anti-hyperglycemic activities of protocatechuic acid (PCA) have protective or therapeutic benefits in obesity management [14].

Among the various types of phenolic acid, benzoic acid derivatives have attracted the most research interest [15]. Sharing similar metabolic pathways (shikimate and phenylpropanoid pathways) [16], the chemical structures of these substances are all positional isomers of phenolic hydroxyl or methoxy groups, and various structures are usually found in the same plant $[5,17]$. For example, $4-\mathrm{HA}$ is a common impurity in natural salicylic acid. Although the primary method for producing salicylic acid is chemical synthesis, 4-hydroxybenzoic acid (4-HA) is often present as a by-product [18]. Therefore, different phenolic acids should be separated and purified as pharmaceutical intermediates, pharmaceuticals, and personal care products.

The main methods currently used to separate phenolic acids are solid-phase extraction (SPE) [19], liquid-liquid extraction (LLE) [20], chromatographic methods [21-24], and other methods, such as capillary electrophoresis [25] and ionic liquid-modified silica gel [26]. These methods are effective for separation, but they have limitations such as being excessively time-consuming, needing high solvent consumption, complicated to control, and producing environmentally damaging wastes $[27,28]$. These limitations have highlighted the need for an alternative simple, rapid and effective separation method, which does not need organic solvents, such as membrane separation.

The separation of similar compounds by molecularly imprinted membranes has been investigated. A surface imprinted layer, attached to a PVDF membrane, was able to separate salicylic acid from acetyl salicylic acid [29]. Molecularly imprinted membranes were able to separate phenol or methyl salicylate from salicylic acid [30,31] This approach is innovative, but industrial production and application of molecularly imprinted membranes is complex and challenging [32], so it would be useful to increase understanding of the interactions between similar phenolic acids and commercial membranes, with a view to enhancing their separation.

To the best of our knowledge, there are no reports on the separation of similar phenolic acids using commercial polymeric membranes. However, there are some on the separation of phenolic acids from other components. Phenolic acids (vanillic acid, p-coumaric acid, and ferulic acid) were separated from monosaccharides using nanofiltration membranes. Under high $\mathrm{pH}$ conditions, the charge on both the membranes and phenolic acids increased, increasing electrostatic repulsion, whereas monosaccharides were electrically neutral [33]. The much higher retention of gallic acid by Biomax $5 \mathrm{k}$ membranes, compared with acetovanillone and esculetin, was attributed to repulsion by the charged membrane surface and the moderate adsorption capacity of the hydrophobic polyethersulfone membrane [34]. Electrostatic repulsion was the main reason for the high retention of acetic acid by polyamide and polyethersulfone membranes operated at $\mathrm{pH} 9$ [35].

During membrane filtration with tight ultrafiltration and nanofiltration membranes, size exclusion, electrostatic and hydrophobic interactions are the main mechanisms that determine the retention rates of different compounds [36,37], so separation of charged compounds (phenolic acids, negative charge) from uncharged components (monosaccharides, no charge) is efficient. However, separation of compounds with similar electrostatic (both positively, negatively, or uncharged) and hydrophobic properties, but with quantitative differences in physicochemical properties, may be facilitated by a better understanding of the relationship between physicochemical properties and penetration through commercial membranes.

The main objectives of this study were: (1) to reveal the mechanisms of electrostatic and hydrophobic interactions on the penetration of similar compounds during ultrafiltration; (2) to separate similar compounds with commercial membranes. Five phenolic acids (gallic acid (GA), protocatechuic acid (PCA), 4-hydroxybenzoic acid (4-HA), 3-hydroxybenzoic acid (3-HA), and salicylic acid (SA)) with similar structures (benzoic acids with only the 
number and position of phenolic hydroxyl groups being different) were selected. To maximize electrostatic and hydrophobic interactions with the membranes, two different materials, polyamide (PA) and regenerated cellulose (RC), with the same molecular weight cutoff (MWCO) of $1000 \mathrm{Da}$, were selected. The observed penetration rates of phenolic acids at different $\mathrm{pH}$ was determined, as well as trial separation of phenolic acid mixtures. To the best of our knowledge, this is the first attempt to separate similar phenolic acids in mixtures by ultrafiltration and may provide reliable guidance for separating and purifying similar natural products using membrane technology.

\section{Materials and Methods}

\subsection{Chemicals}

Five phenolic acid compounds (Shyuanye Corporation, Shanghai, China) were selected as model solutes in this study: gallic acid (GA), protocatechuic acid (PCA), 4hydroxybenzoic acid (4-HA), 3-hydroxybenzoic acid (3-HA), and salicylic acid (SA) were all of analytical grade (Table 1). All compounds were used without purification, and aqueous solutions were prepared with Milli-Q water.

Table 1. Physicochemical properties for the selected phenolic acid compounds.

\begin{tabular}{|c|c|c|c|c|c|c|c|c|c|c|c|}
\hline Compound & $\begin{array}{l}\text { Molecular } \\
\text { Formula }\end{array}$ & $\begin{array}{l}\text { Molecular } \\
\text { Structure }\end{array}$ & $\underset{(\mathrm{g} / \mathrm{mol})}{\mathrm{Mw}}$ & $\begin{array}{l}\text { Stokes } \\
\text { Radius }^{\text {a }} \\
\text { (nm) }\end{array}$ & $\underset{\mathbf{b}}{\mathbf{P K a}}$ & $\mathrm{pH}$ & $\underset{b, d}{\log D}$ & Charge & $\begin{array}{c}\text { Dipole } \\
\text { moment }^{\mathrm{c}} \\
\text { (Debye) }^{\text {Debye }}\end{array}$ & $\begin{array}{c}\text { H- } \\
\text { Bonding } \\
\text { Donors }\end{array}$ & $\begin{array}{l}\text { H-Bonding } \\
\text { Acceptors }\end{array}$ \\
\hline GA & $\mathrm{C}_{7} \mathrm{H}_{6} \mathrm{O}_{5}$ & & 170.12 & 0.295 & 3.94 & 3.27 & 0.63 & -0.19 & -0.44 & 5 & 5 \\
\hline PCA & $\mathrm{C}_{7} \mathrm{H}_{6} \mathrm{O}_{4}$ & & 154.12 & 0.286 & 4.16 & 3.27 & 0.97 & -0.12 & 0.55 & 4 & 4 \\
\hline 4-HA & $\mathrm{C}_{7} \mathrm{H}_{6} \mathrm{O}_{3}$ & & 138.12 & 0.278 & 4.38 & 3.29 & 1.29 & -0.08 & 1.33 & 3 & 3 \\
\hline 3-HA & $\mathrm{C}_{7} \mathrm{H}_{6} \mathrm{O}_{3}$ & & 138.12 & 0.278 & 3.84 & 3.10 & 1.26 & -0.15 & 1.43 & 3 & 2 \\
\hline SA & $\mathrm{C}_{7} \mathrm{H}_{6} \mathrm{O}_{3}$ & & 138.12 & 0.278 & 2.79 & 2.61 & 1.76 & -0.39 & 2.97 & 3 & 2 \\
\hline
\end{tabular}

a Data calculated according to the Stokes-Einstein equation based on the assumption of spherical solutes. Moreover, the diffusivity in the Stokes-Einstein equation was obtained from the Wilke-Chang equation $[38,39] ;{ }^{b}$ Data calculated with ChemAxon (http:/ / www.chemicalize.com, accessed on 9 February 2022); ${ }^{c}$ Data calculated with Chem3D; ${ }^{\mathrm{d}}$ Data determined by $10 \mathrm{mM}$ phenolic acids dissolved in ultrapure water. $\log \mathrm{D}$, apparent partitioning coefficient, which took into account the speciation of the compound at various $\mathrm{pH}$ levels and was used to reflect the hydrophobicity of compounds [40,41].

\subsection{Membrane Characterization}

Two commercial membranes with the same molecular weight cutoff (MWCO) of 1000, regenerated cellulose membrane (MILLIPORE Corp, Burlington, MA, USA), thin-film composite poly(piperazine-amide) membranes (TRISEP Corp, Goleta, CA, USA) were used in this investigation. Table 2 summarizes some relevant characteristics of the investigated membranes. 
Table 2. Membrane properties (N.A. = not applicable).

\begin{tabular}{|c|c|c|}
\hline Membrane & PLAC07610 & UA60 \\
\hline Abbreviation & $\mathrm{RC}$ & PA \\
\hline Structure & $\mathrm{OH} \quad \mathrm{CH}_{2} \mathrm{OH}$ & \\
\hline Manufacturer & MILLIPORE & TRISEP \\
\hline Material & Regenerated Cellulose & Poly (piperazine-amide) \\
\hline $\mathrm{MWCO}(\mathrm{Da})$ & 1000 & 1000 \\
\hline Pore Diameter $\mathrm{d}^{\mathrm{a}}(\mathrm{nm})$ & 1.59 & 1.59 \\
\hline Max. pressure (bar) & 4.8 & $7.6^{b}$ \\
\hline Max. temp. $\left({ }^{\circ} \mathrm{C}\right)$ & 50 & 50 \\
\hline $\mathrm{pH}$ range & $3-13$ & $1-12$ \\
\hline $\mathrm{NaCl}$ rejection (\%) & N.A. & 10 \\
\hline $\begin{array}{l}\text { Water permeability }{ }^{c} \\
\left(\mathrm{~L} / \mathrm{m}^{2} \cdot \mathrm{h} \cdot \mathrm{bar}\right)\end{array}$ & 2.97 & 9.19 \\
\hline Contact angle (water) ${ }^{\mathrm{C}}$ & 23.38 & 30.88 \\
\hline Zeta-potential $(\mathrm{mV}) \mathrm{d}$ & -10.71 & -21.22 \\
\hline
\end{tabular}

${ }^{a}$ Calculation using equation [42]. D = 2.20374 $\times 10^{-11} \cdot \mathrm{MW}^{0.53} ;{ }^{\mathrm{b}}$ Obtained from the literature [43,44]; ${ }^{\mathrm{c}}$ Experimental values measured at $25^{\circ} \mathrm{C} ;{ }^{\mathrm{d}}$ Experimental values measured at $25^{\circ} \mathrm{C}, \mathrm{pH}=5.3 \pm 0.2$.

\subsection{Experimental Procedure}

\subsubsection{Static Adsorption and Soaking Experiment}

In the adsorption experiments, the total surface area of RC and PA membranes was selected to be $83.6 \mathrm{~cm}^{2}$. The membrane was placed in a conical flask containing $130 \mathrm{~mL}$ of solution, which was phenolic acids dissolved in ultrapure water, and the concentration was $10 \mathrm{mM}$. At the same time, a conical flask filled with the same solution but without a membrane was used as a control to exclude the effect of water evaporation on the concentration. Magnetic stirrings were applied in the two conical flasks at $300 \mathrm{rpm}$ and $25^{\circ} \mathrm{C}$, and an equilibration time of $2 \mathrm{~h}$ was used. Samples were taken and filtered through cellulose acetate filters with $0.22 \mu \mathrm{m}$ pore size for subsequent measurement of phenolic acids concentrations.

\subsubsection{Membrane Filtration Experiments}

The RC and PA membranes were tested in a dead-end filtration cell (UFSC40001, Millipore, Burlington, MA, USA), equipped with a magnetic stirring paddle and external pressure supplied by high-purity nitrogen gas. The effective membrane filtration area was $41.8 \mathrm{~cm}^{2}$. The temperature was maintained in penetration experiments at $25^{\circ} \mathrm{C}$. A new membrane specimen was used for each selected phenolic acid compound. New membranes were first soaked in Milli-Q water for approximately $24 \mathrm{~h}$ to remove the chemicals used for membrane preservation. Before each experiment, all of the membranes were compacted with Milli-Q water at 2 bar and magnetic stirrer speed $300 \mathrm{r} \cdot \mathrm{min}^{-1}$ for at least $30 \mathrm{~min}$ until there was no further variation in flux.

After membrane pretreatment, the same membranes were used to measure the flux and penetration rates of solutes selected. During the penetration experiments, the feed solutions were made by dissolving the appropriate chemical amount in Milli- $Q$ water to $10 \mathrm{mmol} \cdot \mathrm{L}^{-1}$. Besides, the 1 and $5 \mathrm{mmol} \cdot \mathrm{L}^{-1}$ feed solutions were also prepared to study the effect of feed concentration, temperature $\left(25^{\circ} \mathrm{C}\right)$, pressure ( 2 bar), and the magnetic stirrer speed $\left(300 \mathrm{r} \cdot \mathrm{min}^{-1}\right)$ was kept constant. Three hundred $\mathrm{mL}$ simulated solutions of five kinds of phenolic acids with different concentrations were added to the membrane cup, and the permeation flux was measured. The membrane filtration was carried out until the permeate volume reached $150 \mathrm{~mL}$. The permeate flow was measured from the permeate 
volume collected for every minute, using an electronic analytical balance. Each test was repeated three times.

The permeate flux was calculated according to the following equation:

$$
J_{v}=\frac{\Delta V}{A_{m} \cdot t}
$$

where $\Delta V$ is the permeate volume $(\mathrm{L})$ collected at the same interval $t(\mathrm{~h})$, and $A_{m}\left(\mathrm{~m}^{2}\right)$ is the active area of the membrane [45].

The observed penetration (similar to the concept of the observed sieving coefficient [46], but with percentage conversion) of every phenolic acid compound was calculated as follows $[47,48]$ :

$$
P_{o b s}(\%)=\frac{C_{p, a v}}{C_{f}} \times 100
$$

where $C_{p, a v}\left(\mathrm{~mol} \cdot \mathrm{L}^{-1}\right)$ is the average solute concentration in the permeate, and $C_{f}$ $\left(\mathrm{mol} \cdot \mathrm{L}^{-1}\right)$ is the solute concentration in the feed.

The adsorbed amounts of phenolic acids in static adsorption experiments were calculated by:

$$
\text { Adsorption }=\left(C_{0}-C_{A}\right) \frac{V}{A_{m}}
$$

where $C_{0}$ and $C_{A}$ are the concentration $\left(\mathrm{mol} \cdot \mathrm{L}^{-1}\right)$ of phenolic acid solutions when membranes are soaked in it at 0 , and $2 \mathrm{~h}, V$ is the adsorption volume $(\mathrm{L})$, and $A_{m}\left(\mathrm{~m}^{2}\right)$ is the active area of the membrane [45].

The separation factor was calculated as follows [33]:

$$
\text { The separation factor }=\frac{X_{P} / Y_{P}}{X_{f} / Y_{f}}
$$

where $X_{P}$ and $Y_{P}$ are the concentrations $\left(\mathrm{mol} \cdot \mathrm{L}^{-1}\right)$ of two kinds of phenolic acids in the permeate, respectively; $X_{f}$ and $Y_{f}$ are the concentrations $\left(\mathrm{mol} \cdot \mathrm{L}^{-1}\right)$ of two kinds of phenolic acids in the feed, respectively.

\subsection{Membrane Characteristic Analysis}

Before testing, all membranes were dried in a vacuum oven at $35^{\circ} \mathrm{C}$ for more than $12 \mathrm{~h}$. Contact angle measurement was performed using a standard Contact Angle Goniometer (DSA100SOP, KRUSS, Hamburg, Germany), and more than nine different locations were selected for each sample. Membrane surface zeta potentials were measured by using an electro-kinetic analyzer (Anton Paar, SurPASS, Graz, Austria).

\subsection{Analytical Methods}

The phenolic acids concentrations were determined by an HPLC system (Agilent Technologies, 1260 Series, Santa Clara, CA, USA) equipped with a UV detector. The LC column used was a ZORBAX SB-C18 (Stable Bond Analytical $4.6 \times 250 \mathrm{~mm}, 5$ Micron). Operating conditions were as follows: flux $1 \mathrm{~mL} \cdot \mathrm{min}^{-1}$, temperature $30^{\circ} \mathrm{C}$, pressure 120 bar, wavelength $280 \mathrm{~nm}$. The mobile phase of gallic acid, protocatechuic acid, 4-hydroxybenzoic acid, and 3-hydroxybenzoic acid was a mixture of 100:0.1 water/formic acid $(v / v)$ (solvent A) and methanol (solvent B). A linear gradient elution for a total run time of 35 min was used as follows: starting from $95 \%$ solvent $A$ and $5 \%$ solvent $B$, reduced to $85 \%$ solvent $A$ over $10 \mathrm{~min}$, reduced to $75 \%$ solvent A over $10 \mathrm{~min}$, to $65 \%$ over $10 \mathrm{~min}$ and finally isocratic for $5 \mathrm{~min}$. Salicylic acid was chromatographed in isocratic elution in $15 \mathrm{~min}$, and the mobile phase was a mixture of 100:0.4 water/acetic acid (v/v) (solvent A) and methanol (solvent B). The system was equilibrated between runs for 30 min using the starting mobile phase composition. All samples were filtered using cellulose acetate filters with $0.22 \mu \mathrm{m}$ pore size and diluted 1:5 with pure water before HPLC analysis. 
The external standard method was applied. Analytical interpolation in a standard calibration curve determined the concentration of phenolic acid compounds from experimental peak areas.

\subsection{Statistical Analysis}

Linear regression was mainly completed with Excel (2019). Variation partitioning analysis (VPA) was introduced to quantify the individual and interactive contributions of electrostatic and hydrophobic interactions to the penetration rates of different phenolic acids. The contribution rates of individual and interactive fouling were calculated from the $\mathrm{R}^{2}$ values based on variance partitioning analysis (VPA) [49]. The analysis was launched with the "vegan" package in the R Studio 2021.09.1 [50-52].

\section{Results}

\subsection{Effect of Phenolic Acids' Adsorption on Membrane}

Immersion of membranes into phenolic acid solutions resulted in solute adsorption onto the membrane surface, with the amount of each phenolic acid adsorbed differing according to its hydrophobicity and solution charge. At the original $\mathrm{pH}$, the carboxyl group of all five phenolic acids dissociated and had a negative charge in solution (Figure 1). The greater the dissociation, the more negatively charged the compound, SA dissociated the most, with the highest negative charge of -0.39 (Table 1). LogD values reflected the hydrophobicity of compounds. The larger the $\log \mathrm{D}$ value, the more hydrophobic the compound. Plotting the effects of hydrophobic and electrostatic interactions on adsorption revealed that adsorption onto the two membranes was affected primarily by hydrophobic interactions (Figure 2) [53]; i.e., higher hydrophobicity resulted in increased adsorption. Although SA had the highest $\log \mathrm{D}$ value (an indicator of hydrophobicity variation with $\mathrm{pH})$, the amount of SA adsorbed to RC membranes was the lowest, apparently because of electrostatic repulsion between SA and the RC membrane. The more hydrophilic surface resulted in lower adsorption of SA onto the RC membrane, relative to the PA membrane.

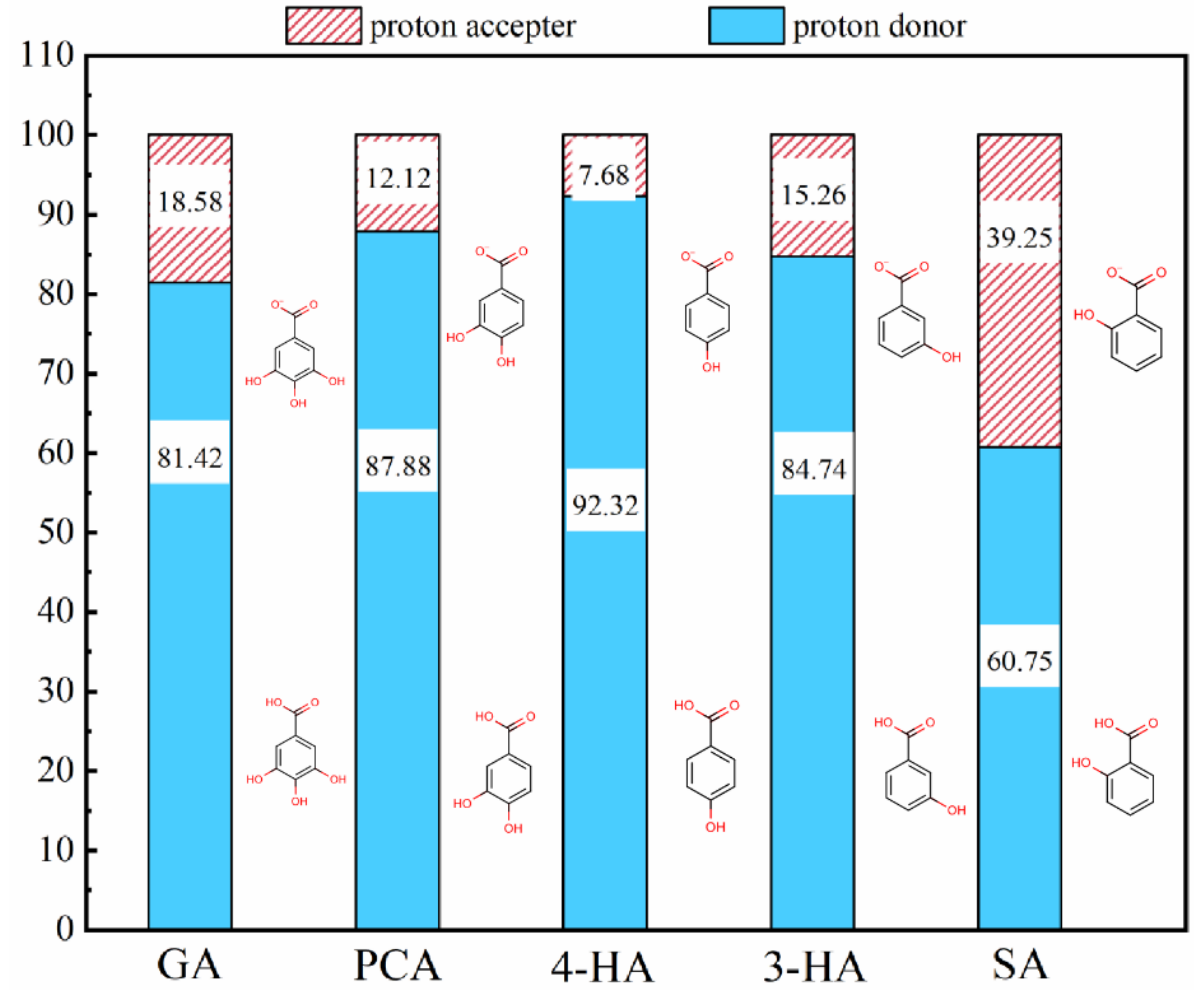

Figure 1. The dissociation percentages of the five phenolic acids at original $\mathrm{pH}$. 

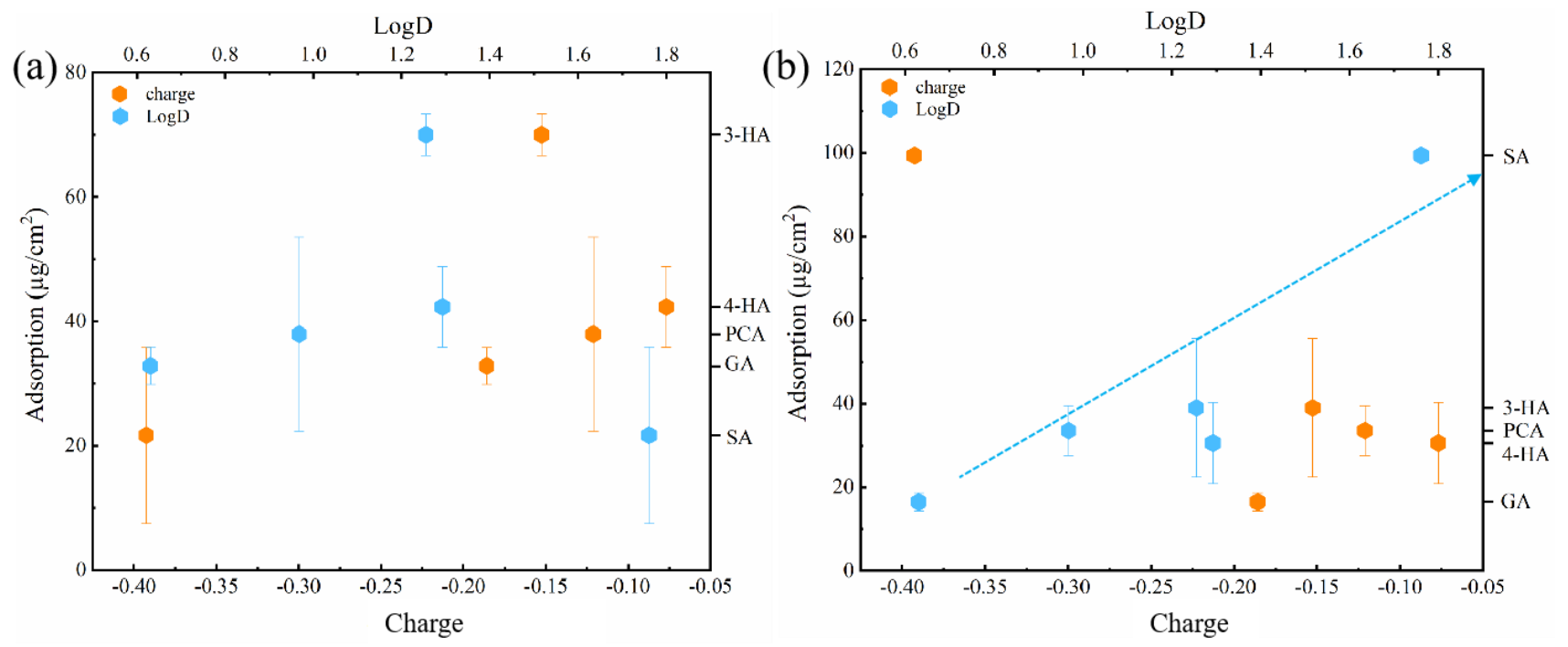

Figure 2. The correlations between amounts of phenolic acids adsorbed onto two membranes ((a), for RC membrane; (b), for PA membrane) and two important physicochemical properties (charge and the $\log \mathrm{D}$ values) of phenolic acids. Experimental conditions: feed concentration $=10 \mathrm{mM}$ and $25 \pm 2{ }^{\circ} \mathrm{C}$. (The error bar is for adsorption).

PCA had greater adsorption than 4-HA onto PA membranes, probably related to the different hydrogen-bonding interactions, based on differences in the numbers of hydrogenbond donors and acceptors [54,55].

The pure water flux after phenolic acid adsorption was measured (Figure 3); the flux of the RC membrane increased after SA adsorption, whereas that of the PA membrane decreased (Figure S1 presented the pure water flux before and after the adsorption of GA, PCA, 4-HA, and 3-HA). This suggests that the change in membrane flux was related to the different properties of the two membranes and the resulting changes following adsorption of the phenolic acids.

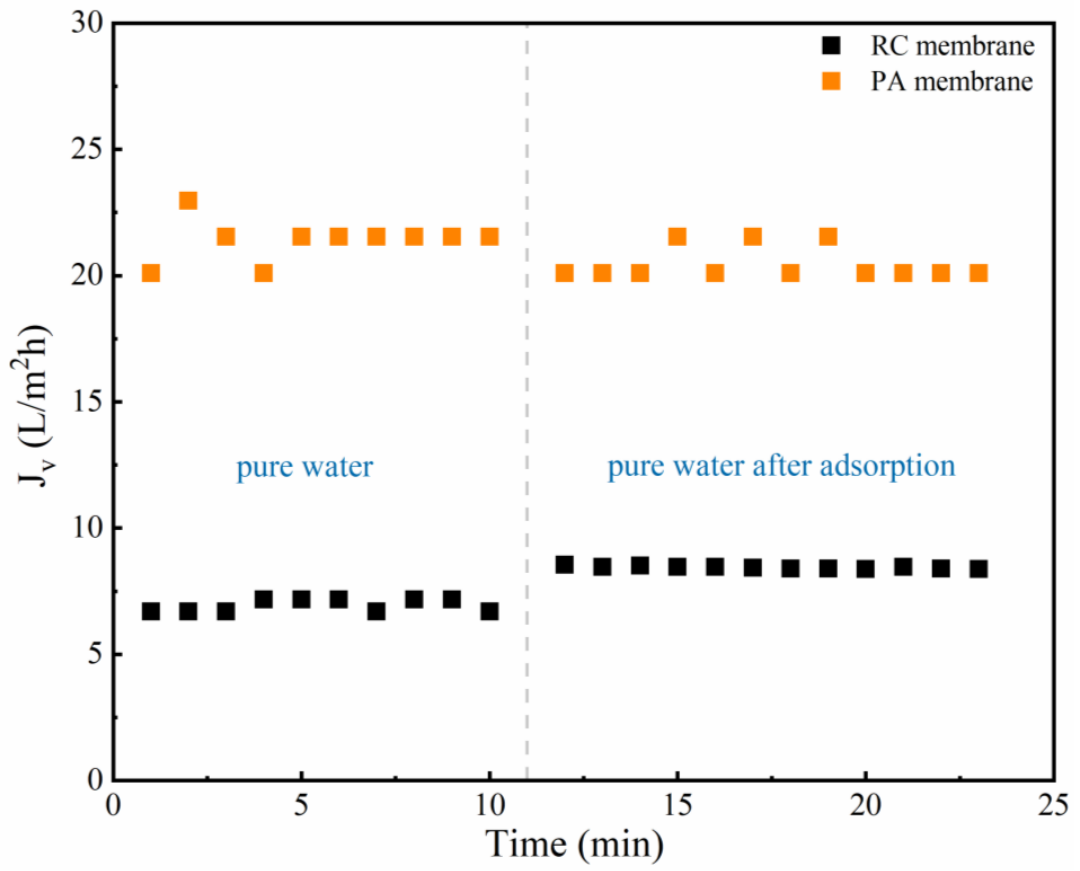

Figure 3. Pure water flux before and after the adsorption of SA on the two membranes. Experimental conditions: 2 bar; feed concentration $=10 \mathrm{mM}$ and $25 \pm 2{ }^{\circ} \mathrm{C}$. 
Figures 4 and 5 show the contact angle analysis and the zeta potential of the membranes after immersion in the different phenolic acids solutions for two hours. The RC membrane became more hydrophilic and less negative, whereas the PA membrane became more hydrophobic and more negative, after the adsorption of phenolic acids.

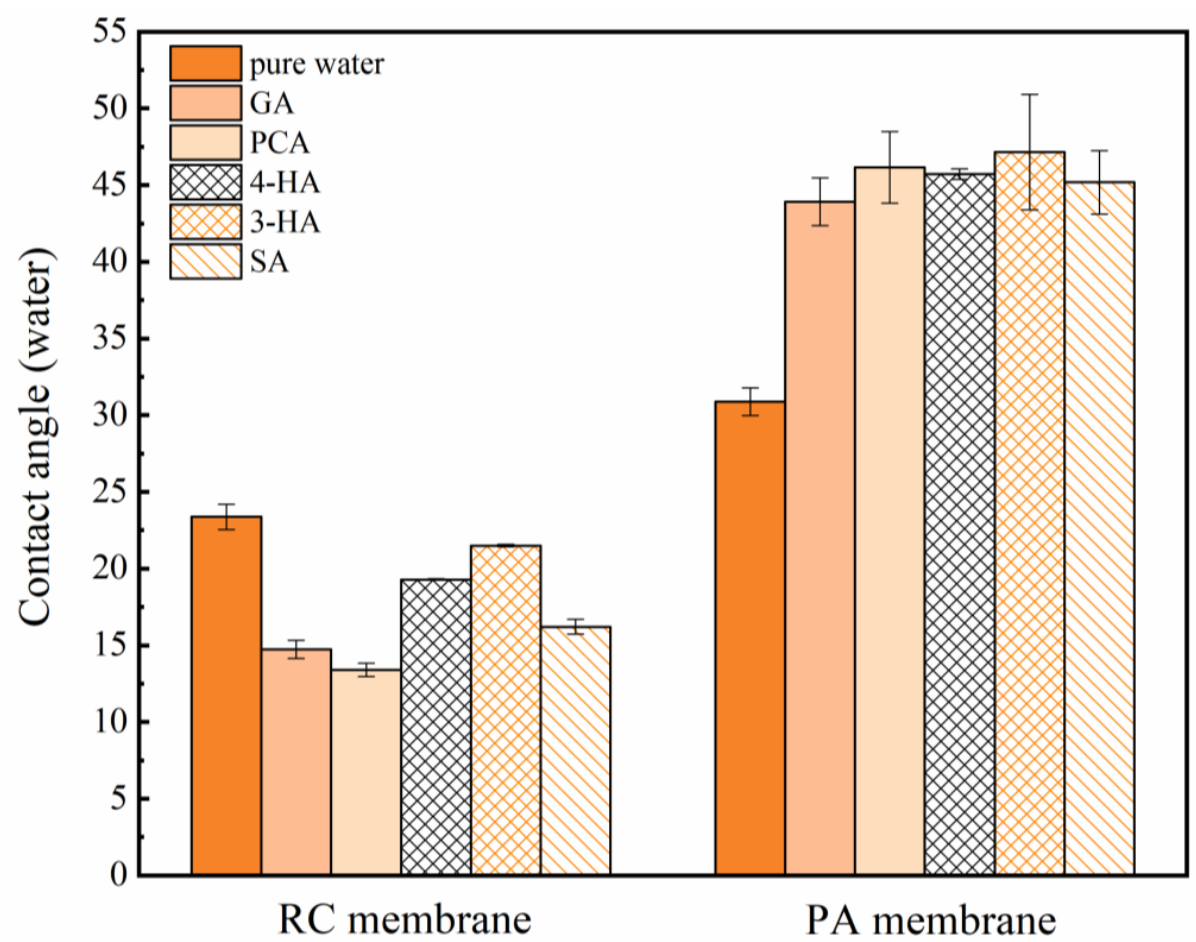

Figure 4. The water contact angle of RC and PA membrane after soaking in pure water and phenolic acids for $2 \mathrm{~h}$. Experimental conditions: feed concentration $=10 \mathrm{mM}$ and $25 \pm 2{ }^{\circ} \mathrm{C}$.

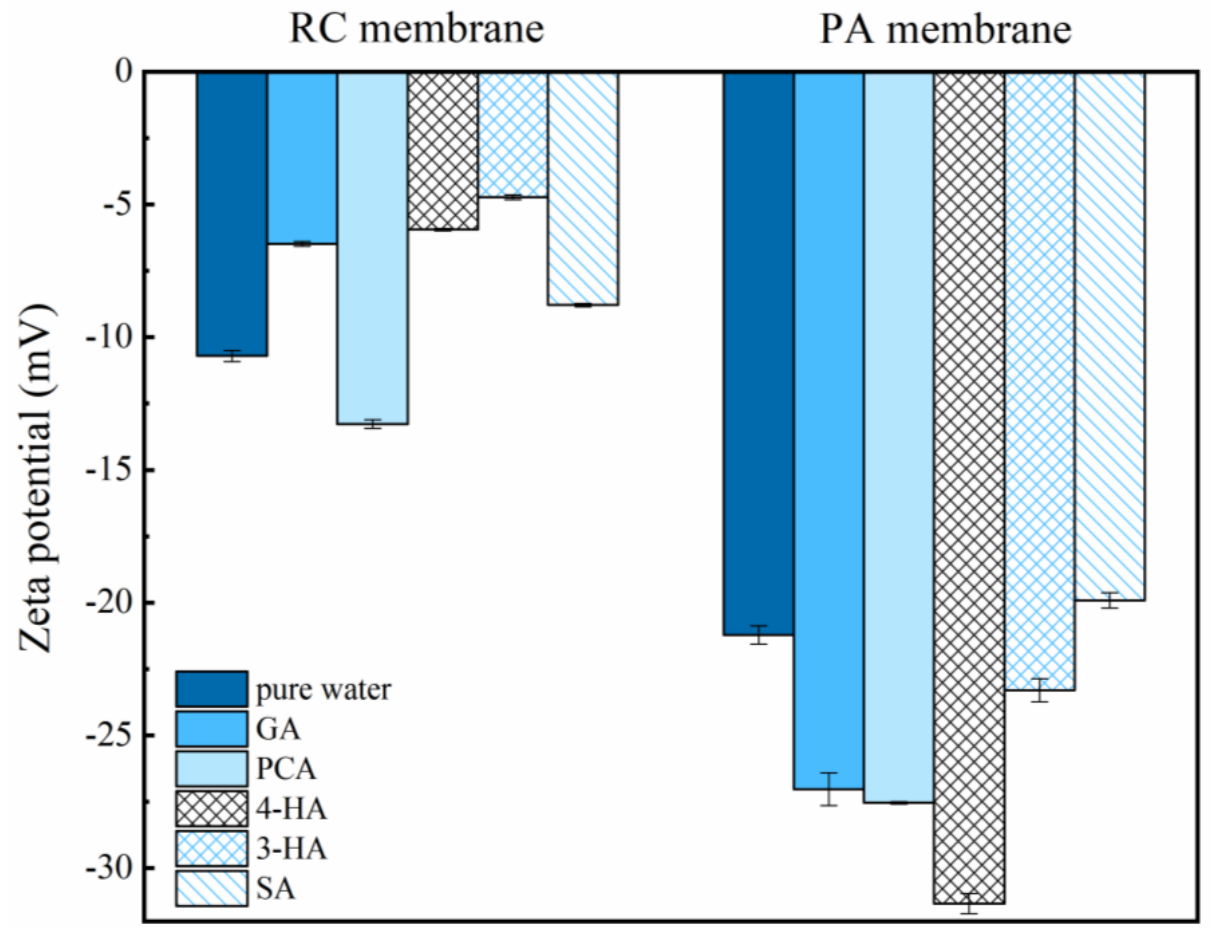

Figure 5. Zeta potential of RC and PA membrane after soaking in pure water and phenolic acids for $2 \mathrm{~h}$. Experimental conditions: feed concentration $=10 \mathrm{mM}$ and $25 \pm 2{ }^{\circ} \mathrm{C}$. 


\subsection{Membrane Separation Capability}

3.2.1. Effect of Phenolic Acids on Filtration Flux

Permeate flux variations were determined during and after phenolic acid ultrafiltration, using the PA and RC membranes, and compared with phenolic acid adsorption and pure water flux (Figure 6). The permeate flux of the RC membrane remained slightly increased with SA, whereas that of the PA membrane decreased. After filtration and adsorption experiments, the pure water flux increased through the RC membrane and decreased through the PA membrane. Taking into account the difference in membrane molecular weight cut-off (1000 Da) and the molecular weight of the selected phenolic acid (138-179 Da), the flux changes appear to be related to variations in the properties of the membrane surfaces, caused by contact with the solutes (Figures 4 and 5) [56,57] (see Table S1 for the pure water flux loss (\%) of different phenolic acids after filtration and adsorption; see Table S2 and Figure S3 for Membrane surface tensions and interfacial free energies analysis; see Figures S5 and S6 for surface SEM morphology of the original and fouled membranes).

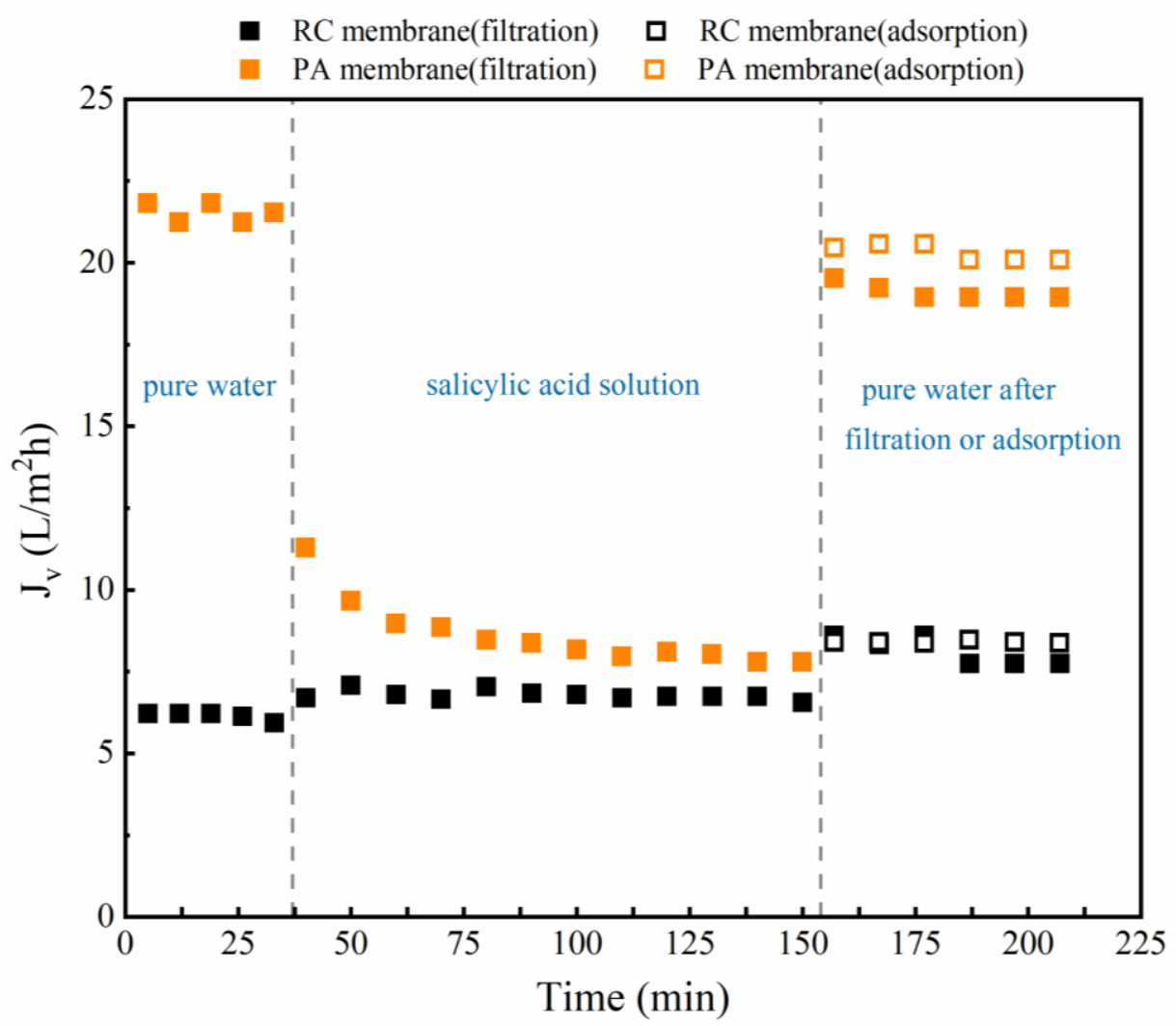

Figure 6. The evolution of the flux of SA during the two membrane filtration processes and water before and after the filtration and adsorption experiments over time. In the last column, the solid point represents the pure water flux after filtration, while the hollow point represents the pure water flux after soaking in phenolic acid solution. Experimental conditions: 2 bar; feed concentration $=10 \mathrm{mM}$ and $25 \pm 2{ }^{\circ} \mathrm{C}$.

\subsubsection{Different Phenolic Acids Penetration Rates}

The fouling of the PA and RC membranes was relatively light (see above) and the MWCO of both membranes was $1000 \mathrm{Da}$, much higher than the molecular weight of the tested phenolic acids (there was no significant difference in their Stokes radii), so the membranes cannot retain phenolic acids based on size-exclusion. This suggests that the charge and hydrophobicity of each phenolic acid are the factors determining their penetration rates. The observed penetration rates of the phenolic acids differed between compounds, but were similar for each compound for the two membranes (>90\%). 
The correlations between the amounts of phenolic acids adsorbed on the two membranes and their penetration rates (Figure 7), revealed a trend of decreased penetration rate for the PA membrane with increased solute adsorption $\left(R^{2}=0.88\right.$, Figure S5), in agreement with a previous report [58]. In contrast, no clear penetration trend was observed in relation to adsorption by the RC membrane, which may be related to its greater hydrophilicity.

(a)

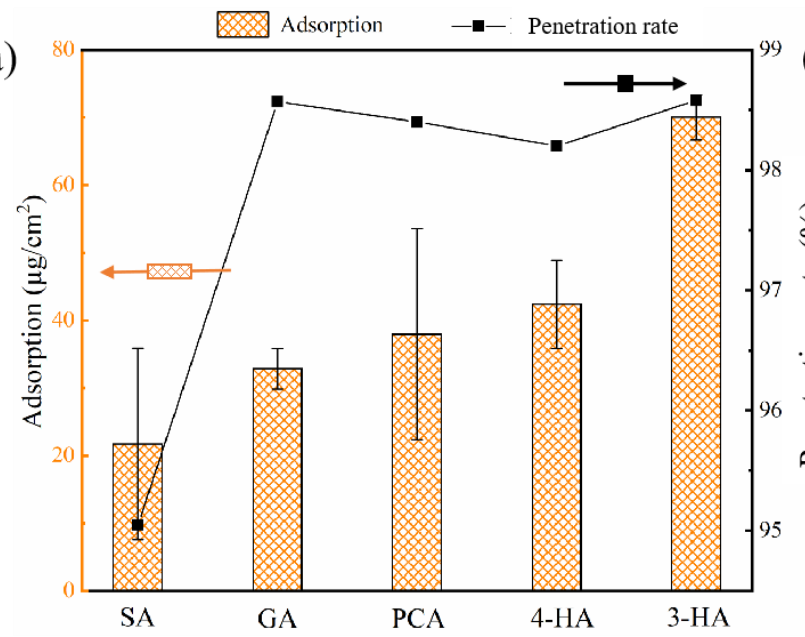

(b)

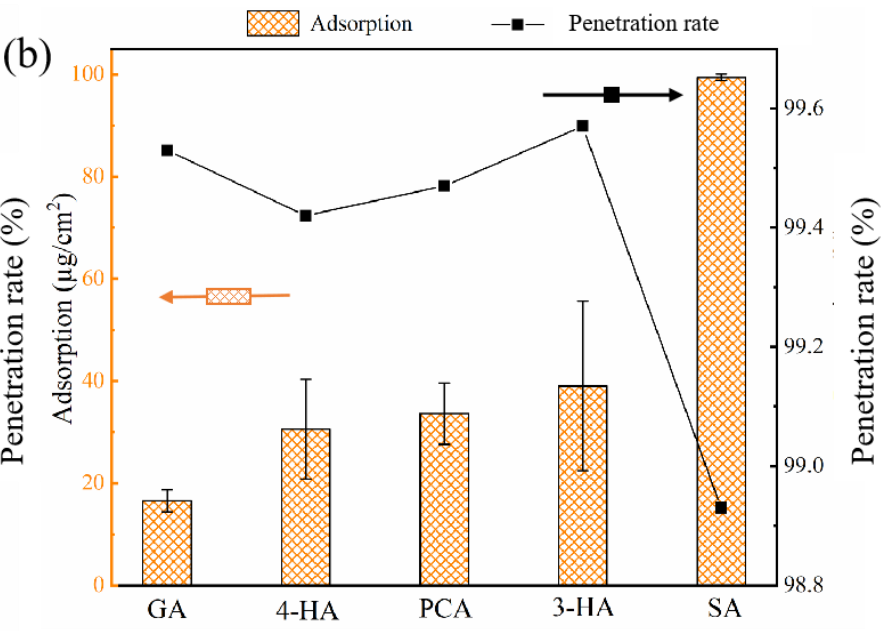

Figure 7. The correlations between amounts of phenolic acids adsorbed onto the two membranes $((\mathbf{a})$, for RC membrane; (b), for PA membrane) and the penetration rates. Experimental conditions: feed concentration $=10 \mathrm{mM}$ and $25 \pm 2{ }^{\circ} \mathrm{C}$.

Correlations between phenolic acid properties and penetration rates were then analyzed (Figure 8). A better correlation was found between the charge and penetration, i.e., the electrostatic interaction mainly influenced the penetration of phenolic acids through RC and PA membranes. Through both membranes, phenolic acid penetration decreased with their negative charge, because of electrostatic repulsion [59]. In addition, hydrophobic interactions also contributed to the penetration of phenolic acids. Moreover, the larger dipole moment of 3-HA resulted in increased penetration by the $\mathrm{RC}$ membrane relative to PCA, in agreement with a previous report $[60,61]$.
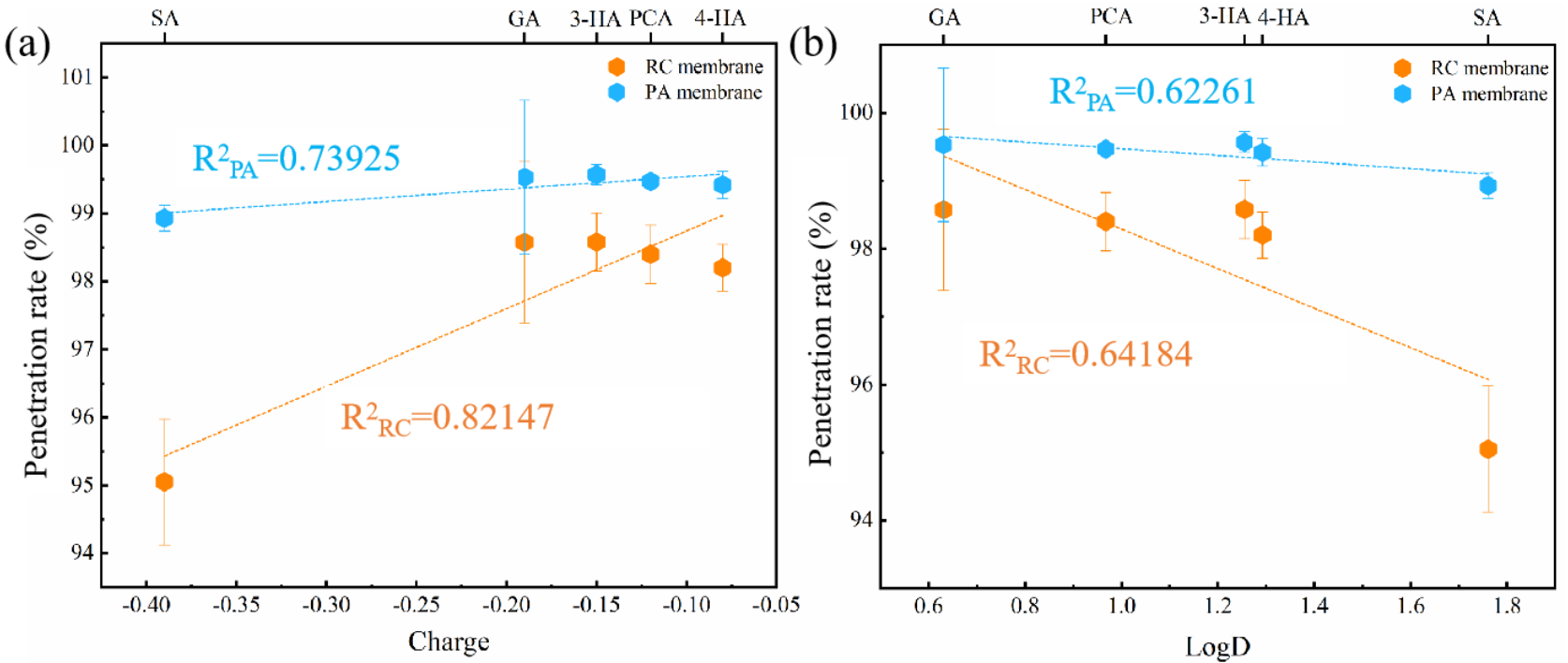

Figure 8. The correlations between the penetration rates of five phenolic acid compounds through the two membranes and two important physicochemical properties $((\mathbf{a})$, for charge, $(\mathbf{b})$, for $\log \mathrm{D}$ values) of phenolic acids. Experimental conditions: 2 bar; feed concentration $=10 \mathrm{mM}$ and $25 \pm 2{ }^{\circ} \mathrm{C}$. 


\subsubsection{Effect of Phenolic Acids' Concentration}

SA penetration through the RC and PA membranes showed an increasing trend with increasing SA concentration (Figure 9). This may be explained as follows: First, a higher feed concentration may increase solute diffusion and induce a high solute penetrate across the membrane $[56,62]$. Second, concentration polarization (CP) increased with the solute concentration. The $\mathrm{CP}$ layer at high concentration would reduce the water flux and increase solute permeability [63] (Figure S4 present the GA, PCA, 4-HA, and 3-HA's concentration on the penetration). To reduce the influence of $\mathrm{CP}$ and increase the influence of electrostatic and hydrophobic effects, the concentration of phenolic acid in the remaining experiments was limited to $1 \mathrm{mM}$.

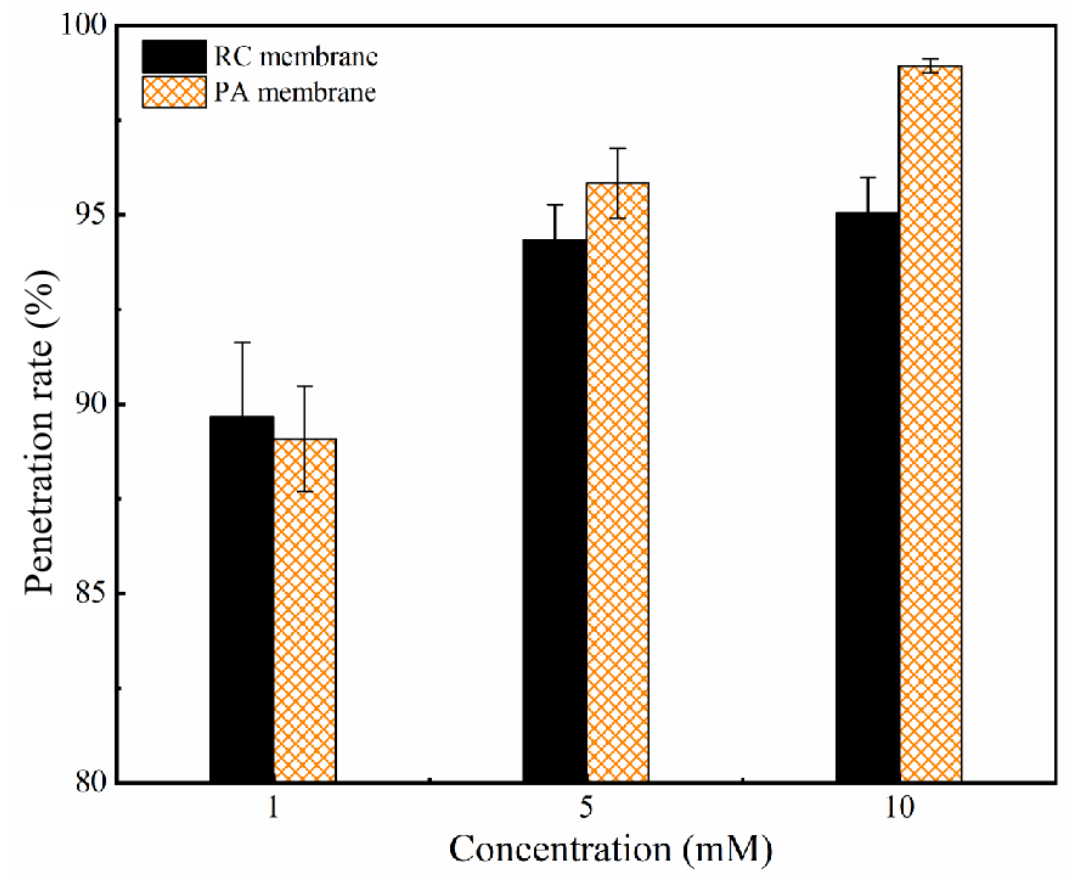

Figure 9. Effect of SA concentration on the penetration rates for these two membranes. Experimental conditions: 2 bar; feed concentration $=1,5,10 \mathrm{mM}$ and $25 \pm 2{ }^{\circ} \mathrm{C}$.

\subsubsection{Effect of $\mathrm{pH}$}

The effect of solution $\mathrm{pH}$ on the observed penetration rates of the five phenolic acids through the membranes was evaluated. Experiments were performed at $\mathrm{pH}$ values of 3.0, 7.4, and 9.0 (except for GA, which degrades irreversibly above $\mathrm{pH} 7$ ) [64]. The different dissociation behaviors of the phenolic acids at these three $\mathrm{pH}$ levels results in different charges (Figure 10). At pH 3.0, the dissociation was basically the same as that of the original solution, except that the carboxyl of salicylic acid dissociated significantly more. At pH 7.4, the carboxyl groups of the phenolic acids in the solution were almost completely dissociated, as well as a small proportion of the hydroxyl groups. At $\mathrm{pH} 9.0$, the increases in negative charge and the decreases in $\log \mathrm{D}$ values of PCA, 4-HA, and 3-HA resulted from increased hydroxyl dissociation. Only the carboxyl group of SA dissociated, so there was little change in charge, or logD.

Phenolic acid penetration generally decreased significantly with pH (Figure 11 \& Table S3). At a higher $\mathrm{pH}$, the membranes become more negatively charged [65] and the phenolic acids more extensively ionized, more negatively charged and more hydrophilic (Table 3), which is in agreement with previous reports [33-35,66]. At $\mathrm{pH}=9.0$, the penetration rate of SA was higher than that of PCA, 4-HA, and 3-HA, Two possible reasons may explain this result. One is that SA has the least charge of the three compounds at $\mathrm{pH}=9.0$ $(-1)$, the other is that the easier formation of intramolecular hydrogen bonds would make SA less likely to aggregate and its penetration easier $[67,68]$. 

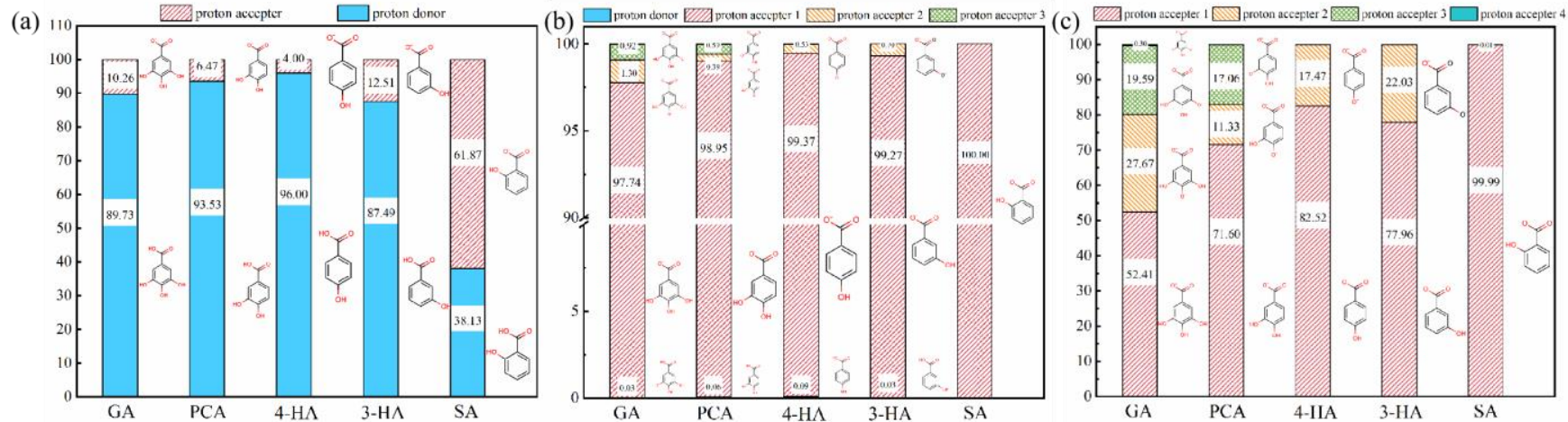

Figure 10. The dissociation percentages of the five phenolic acids at different $\mathrm{pH}((\mathbf{a})$, for $\mathrm{pH}=3.0$; $(\mathbf{b})$, for $\mathrm{pH}=7.4$; $(\mathbf{c})$, for $\mathrm{pH}=9.0)$. feed concentration $=1 \mathrm{mM}$.
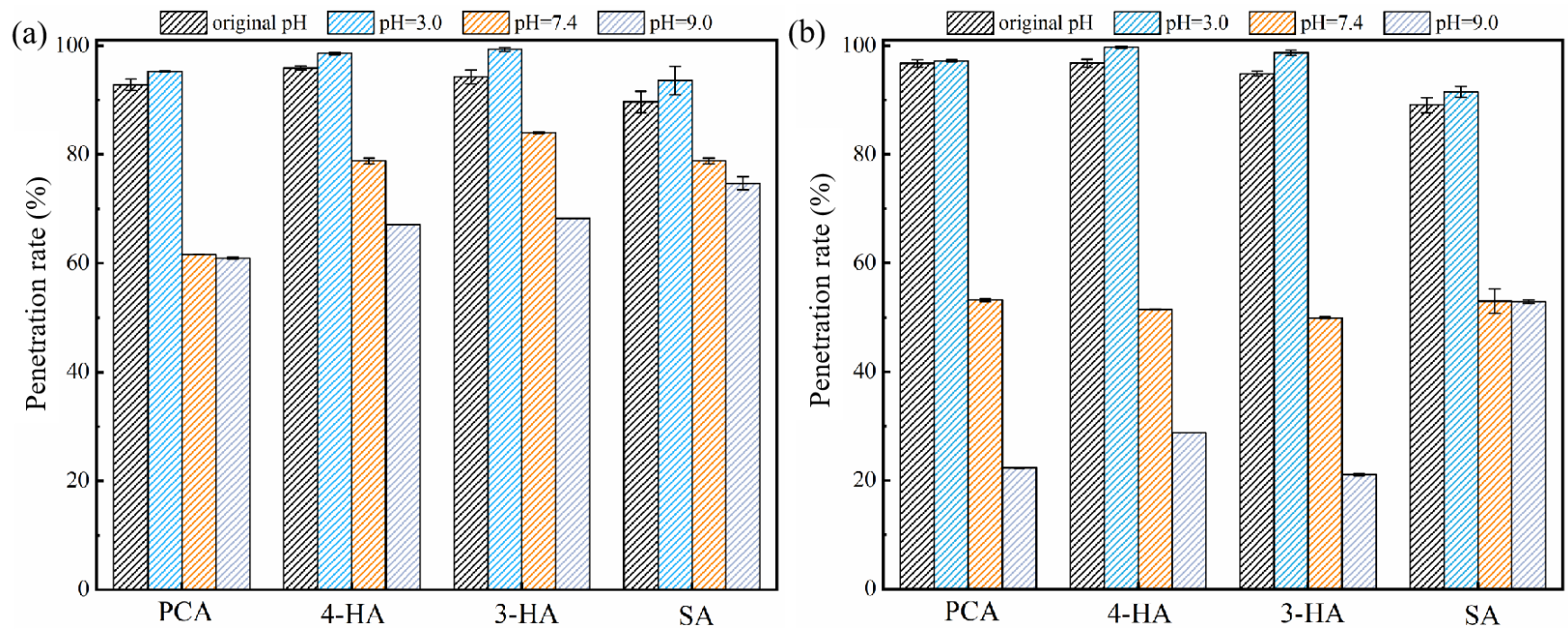

Figure 11. Effect of $\mathrm{pH}$ on the penetration rates of phenolic acids for the two membranes ((a), for RC membrane; (b), for PA membrane). Experimental conditions: 2 bar; feed concentration $=1 \mathrm{mM}$ and $25 \pm 2{ }^{\circ} \mathrm{C}$.

Table 3. The properties of phenolic acids at different $\mathrm{pH}$ (feed concentration $=1 \mathrm{mM}$.).

\begin{tabular}{ccccccccc}
\hline \multirow{2}{*}{$\mathbf{p H}$} & \multicolumn{4}{c}{ Charge $^{\mathbf{a}}$} & \multicolumn{3}{c}{ LogD $^{\mathbf{a}}$} \\
\cline { 2 - 9 } & PCA & 4-HA & 3-HA & SA & PCA & 4-HA & 3-HA & SA \\
\hline original $^{\mathrm{b}}$ & -0.22 & -0.14 & -0.31 & -0.72 & 0.92 & 1.26 & 1.17 & 1.42 \\
3.0 & -0.07 & -0.04 & -0.13 & -0.62 & 0.99 & 1.31 & 1.27 & 1.56 \\
7.4 & -1.00 & -1.00 & -1.00 & -1.00 & -2.04 & -1.58 & -1.92 & -1.52 \\
9.0 & -1.28 & -1.18 & -1.22 & -1.00 & -2.63 & -2.25 & -2.30 & -1.55 \\
\hline
\end{tabular}

${ }^{a}$ Data calculated with ChemAxon (http:/ / www.chemicalize.com, accessed on 9 February 2022); ${ }^{\mathrm{b}}$ The original $\mathrm{pH}$ of phenolic acids were 3.62 for PCA, 3.63 for 4-HA, 3.46 for 3-HA, 3.23 for SA.

Phenolic acid penetration through the PA membrane was influenced by $\mathrm{pH}$ more than that through the $\mathrm{RC}$ membrane; increasing the $\mathrm{pH}$ from 3.0 to 7.4 decreased PCA penetration through the PA membrane from $98 \%$ to $30-50 \%$ (Figure 11). A more negatively charged and hydrophilic surface, which would have become even more negative and hydrophilic after adsorption of phenolic acids (Figures 4 and 5), may explain why penetration was more variable through the PA membrane.

Previous reports mainly focused on separating phenolic acids from other substances, mostly sugars and phenolics, which are uncharged at $\mathrm{pH}<8[22,61]$. However, the phenolic 
acids selected are all negatively charged at $\mathrm{pH}$ above $\sim 2$. Although structural differences between them were minor, the effect of $\mathrm{pH}$ on their charge and hydrophilicity was different, resulting in different permeabilities.

Plots of penetration against the charge and $\log \mathrm{D}$ value of the phenolic acids (Figure 12), showed a good correlation between penetration rates and charge, or $\log \mathrm{D}\left(\mathrm{R}^{2}>0.9\right)$. In addition, penetration rates decreased with decreasing $\log \mathrm{D}$ values, which differed from the observed relationship between adsorption and penetration. Possible reasons are as follows: First, membrane adsorption during filtration initially resulted in the retention of hydrophobic compounds. However, the continued transport of solutes established an equilibrium, resulting in greater retention of relatively hydrophilic compounds than relatively hydrophobic compounds [69-72]. Second, after reaching equilibrium, electrostatic repulsion would be the dominant mechanism increasing retention of phenolic acids [73].
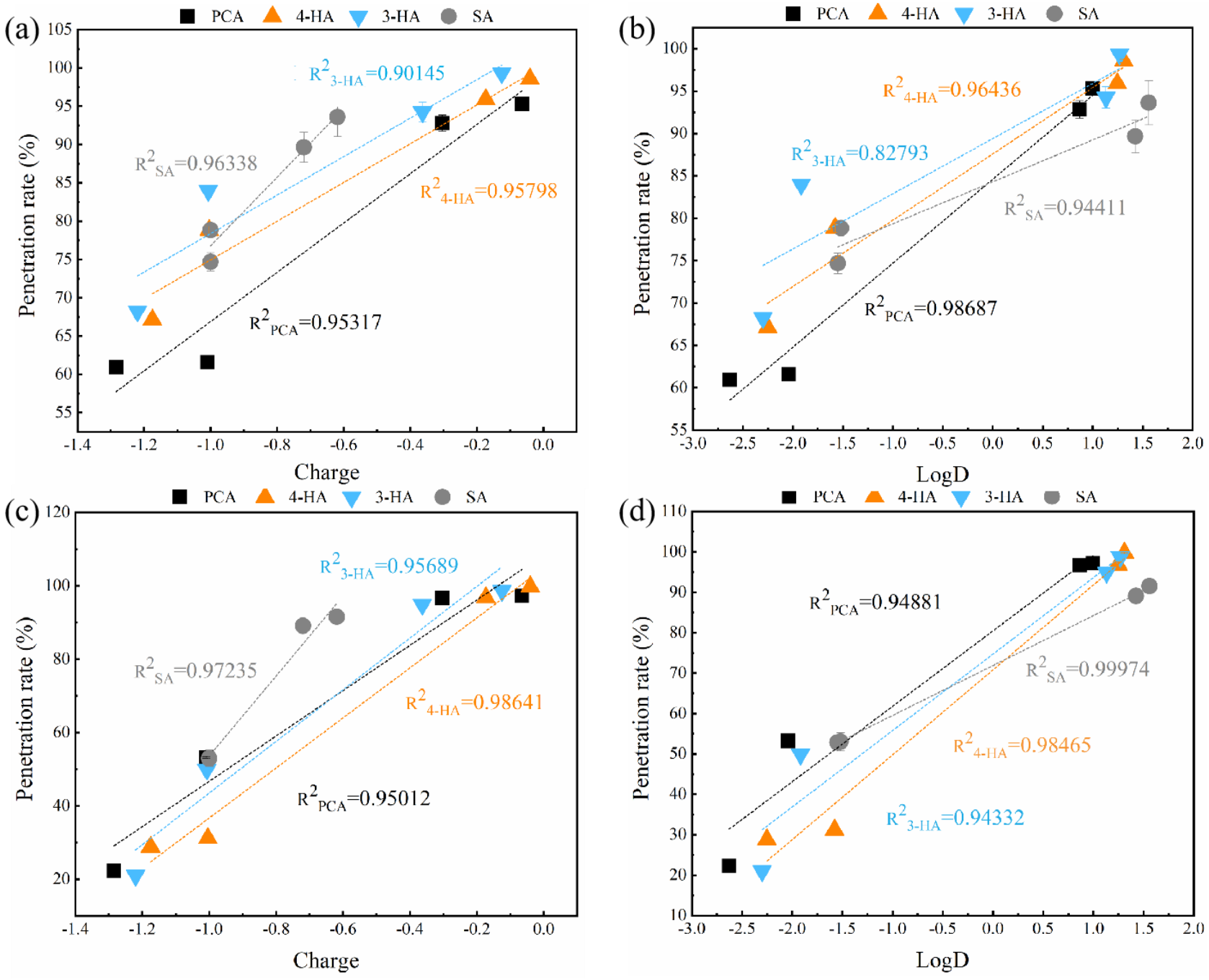

Figure 12. The correlations between the penetration rates of four phenolic acid compounds at different $\mathrm{pH}$ on the two membranes $((\mathbf{a}, \mathbf{b})$ for RC membrane; $(\mathbf{c}, \mathbf{d})$ for PA membrane) and two important physicochemical properties (charge and the $\log \mathrm{D}$ values) of phenolic acids. Experimental conditions: 2 bar; feed concentration $=1 \mathrm{mM}$ and $25 \pm 2{ }^{\circ} \mathrm{C}$.

3.2.5. Relative Influence of Electrostatic and Hydrophobic Interactions on Phenolic Acid Membrane-Penetration

The contribution rate of electrostatic and hydrophobic interactions on phenolic acid penetration through $\mathrm{RC}$ and PA membranes, without $\mathrm{pH}$ adjustment, at pHs 3.0 and 9.0 was calculated by Variation Partitioning analysis (VPA) (Figures 13 and 14). The result at 
$\mathrm{pH} 7.4$ is not shown because the charge on all of the phenolic acids was -1.00 at $\mathrm{pH} 7.4$, making calculation impossible.

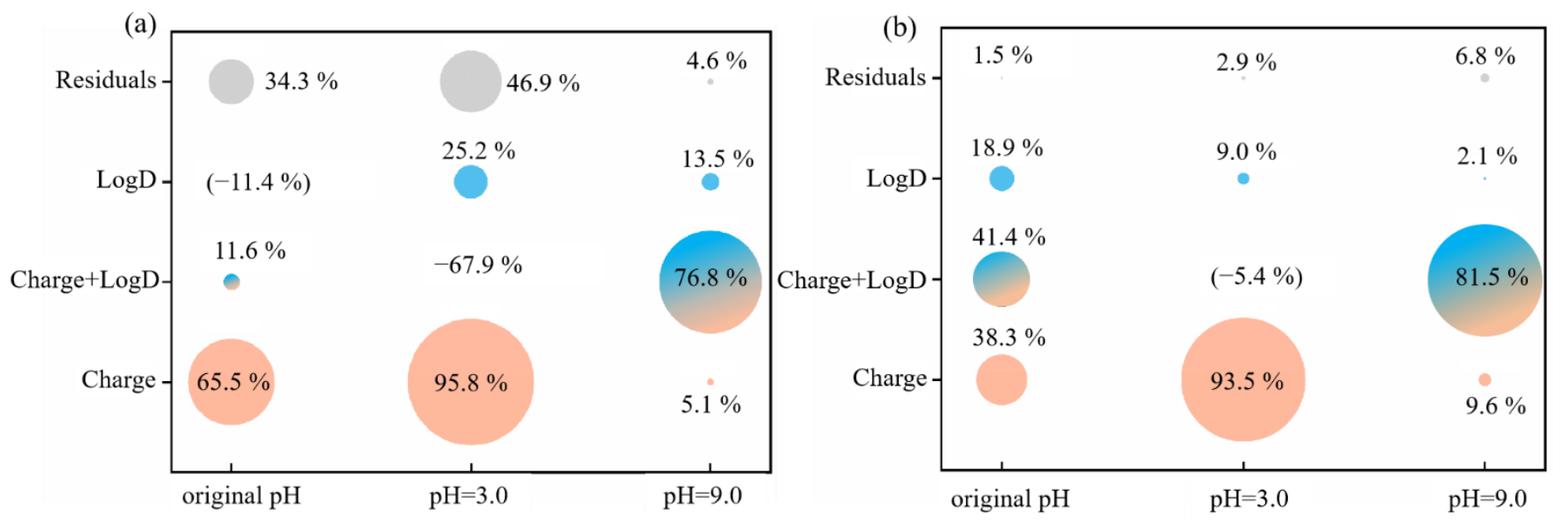

Figure 13. The contributions of different variables to the penetration rates of phenolic acids in two membranes under different solution conditions ((a), for RC membrane; (b), for PA membrane).

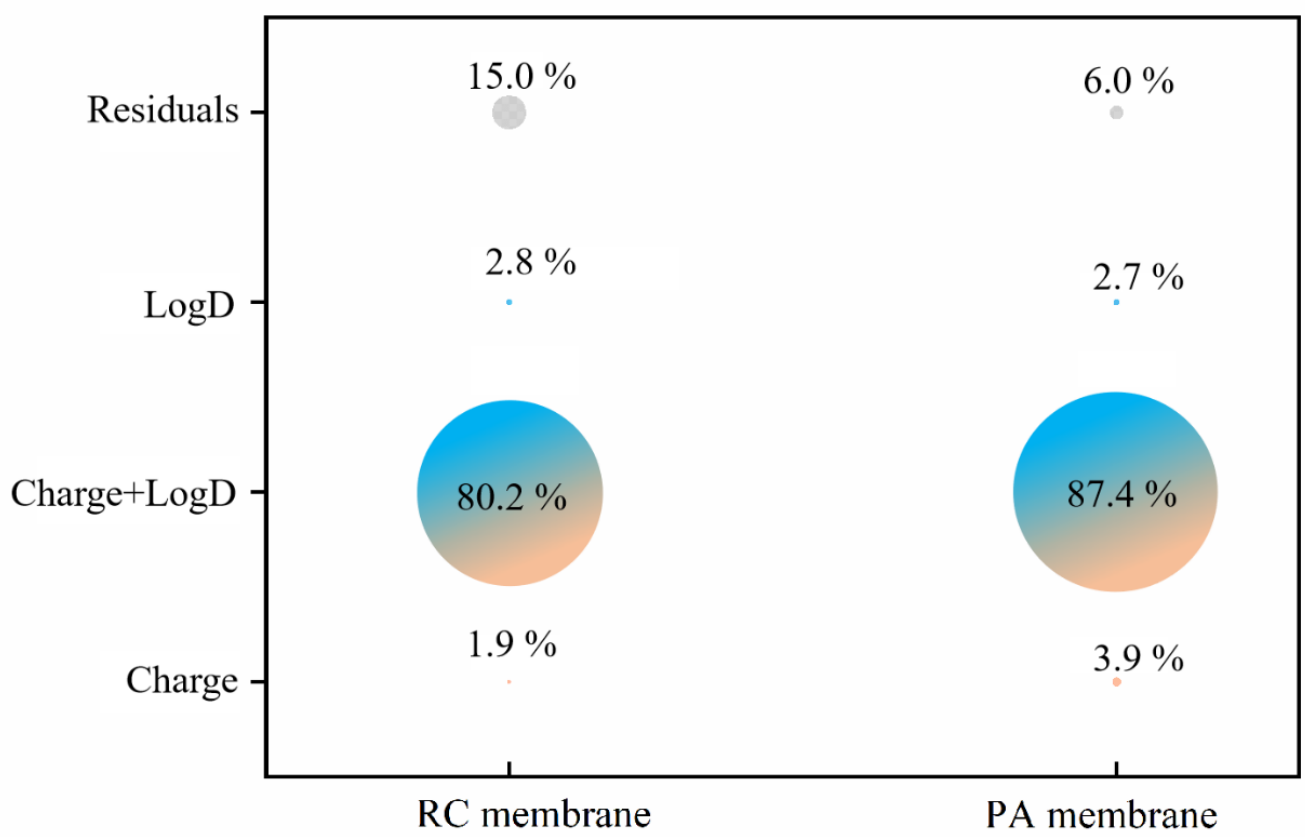

Figure 14. The contributions of different variables to the penetration rates of phenolic acids in RC and PA membrane (overall analysis).

Without $\mathrm{pH}$ adjustment, the contribution of the charge to phenolic acid penetration through the RC membrane was $65.5 \% . \log \mathrm{D}$ (hydrophobic interactions) made a negative contribution $(-11.4 \%)$ to $\mathrm{RC}$ penetration, but it reduced the residual through shared variation of charge (11.6\%). However, for the PA membrane, the contributions were charge $38.3 \%, \log \mathrm{D} 18.9 \%$ and a combined effect of $41.4 \%$. When the solution $\mathrm{pH}$ was adjusted to 3.0, charge dominated the effect on both membranes, contributing $95.8 \%$ to RC and 93.5\% to PA membrane penetration. This provides a plausible explanation for the data in Sections 3.2.2 and 3.2.4.

VPA of all $\mathrm{pH}$ (Figure 14) showed that the combined effect of charge and $\log \mathrm{D}$ was the primary penetration mechanism for phenolic acids through both RC and PA membranes. In addition, the residuals were $15.0 \%$ for RC and $6.0 \%$ for PA membranes. Researchers 
often attributed the effect of $\mathrm{pH}$ on solute penetration to electrostatic repulsion between membrane and solutes [33-35,66]. However, based on the VPA analysis, the electrostatic interaction does have a major impact, but the hydrophobic effect should never be ignored. In addition, electrostatic and hydrophobic effects had a greater influence during separation with the PA membrane, which had a residual of only $6.0 \%$. This could explain why the surface of the PA membrane was more sensitive to the differences between phenolic acids.

In addition, two QSAR models for RC and PA membranes under all $\mathrm{pH}$ conditions showed how the relationships between penetrations and phenolic acid's parameters were developed, as Equations (5) and (6), respectively. The correlation coefficients of these QSAR models were $\mathrm{R}_{R C}^{2}=0.8583$ and $\mathrm{R}_{P A}^{2}=0.9331$. The $\mathrm{R}^{2}$ of the QSAR model for PA membrane is closer to 1 , and is more significantly influenced by charge and $\log \mathrm{D}$.

$$
\begin{aligned}
& P_{\text {obs } b s}=92.33+9.27 \times \text { Charge }+5.50 \times \log D \\
& P_{\text {obs }}=90.54+29.07 \times \text { Charge }+10.28 \times \log D
\end{aligned}
$$

It should be noted that the influence of hydrogen bonding $[74,75]$ on adsorption and penetration was not analyzed. Liu et al. [76] analyzed the impacts of electrostatic and non-electrostatic interactions (including hydrophobic interaction and hydrogen bonding) by comparing adsorption at the isoelectric point (IEP) of different membranes. However, hydrogen bonds are difficult to quantify and usually occur along with hydrophobic interactions. The smaller residual values also verified the dominant contribution of the combined electrostatic/hydrophobic effect and suggest that hydrogen bonding and sieving (steric-hindrance) have little effect on phenolic acid penetration in this study.

Due to the differences in molecular structure and different dissociation states, the penetration rates of different phenolic acids varied significantly with $\mathrm{pH}$ and the trends were different (Figure 11). For example, at $\mathrm{pH}$ 9.0, penetration of 4-HA, SA and PCA through the PA membrane was $28.8 \%, 52.9 \%$, and $22.3 \%$, respectively, suggesting that a better separation of similar phenolic acids may be achievable with membrane technology, only by controlling the $\mathrm{pH}$ of the mixture solution.

\subsection{Practical Separation of Different Phenolic Acids in Mixtures}

It appeared from the findings above, that controlling the solution $\mathrm{pH}$ could achieve a useful separation of phenolic acids. Two binary mixtures, PCA+SA and 4-HA+SA, were selected to test the effectiveness of $\mathrm{pH}$ control. As mentioned above, PCA and 4-HA are often present as impurities in SA. With the PA membrane at $\mathrm{pH} 9.0$, the separation factors of SA/4-HA and SA/PCA were 1.81 and 1.78, respectively. In contrast, the separation factors of the RC membrane were generally small, the penetration rates of PCA, 4-HA, and SA in the mixtures were higher than when they were filtered separately (Figure 15). The explanation could be that adsorption of phenolic acids makes the RC membrane less negatively charged and more hydrophilic, which decreased the electrostatic repulsion and hydrophobic interactions between the membrane surface and all the phenolic acids. In contrast, the PA membrane became more negatively charged and more hydrophobic after contact with phenolic acids, which may be the reason why the PA membrane can separate similar phenolic acids.

The phenolic acids selected are structurally similar, with differences only in the number and position of their phenolic hydroxyl groups. However, quantity differences in charge and hydrophobicity can apparently be used to separate them. The result may provide a facile method for separating phenolic acids and guidance for improving membrane materials [77]. It is well accepted that a more hydrophilic surface would have greater resistance to fouling $[78,79]$. However, the findings of this study suggest that a more hydrophobic and charged membrane may also be able to separate similar compounds. 

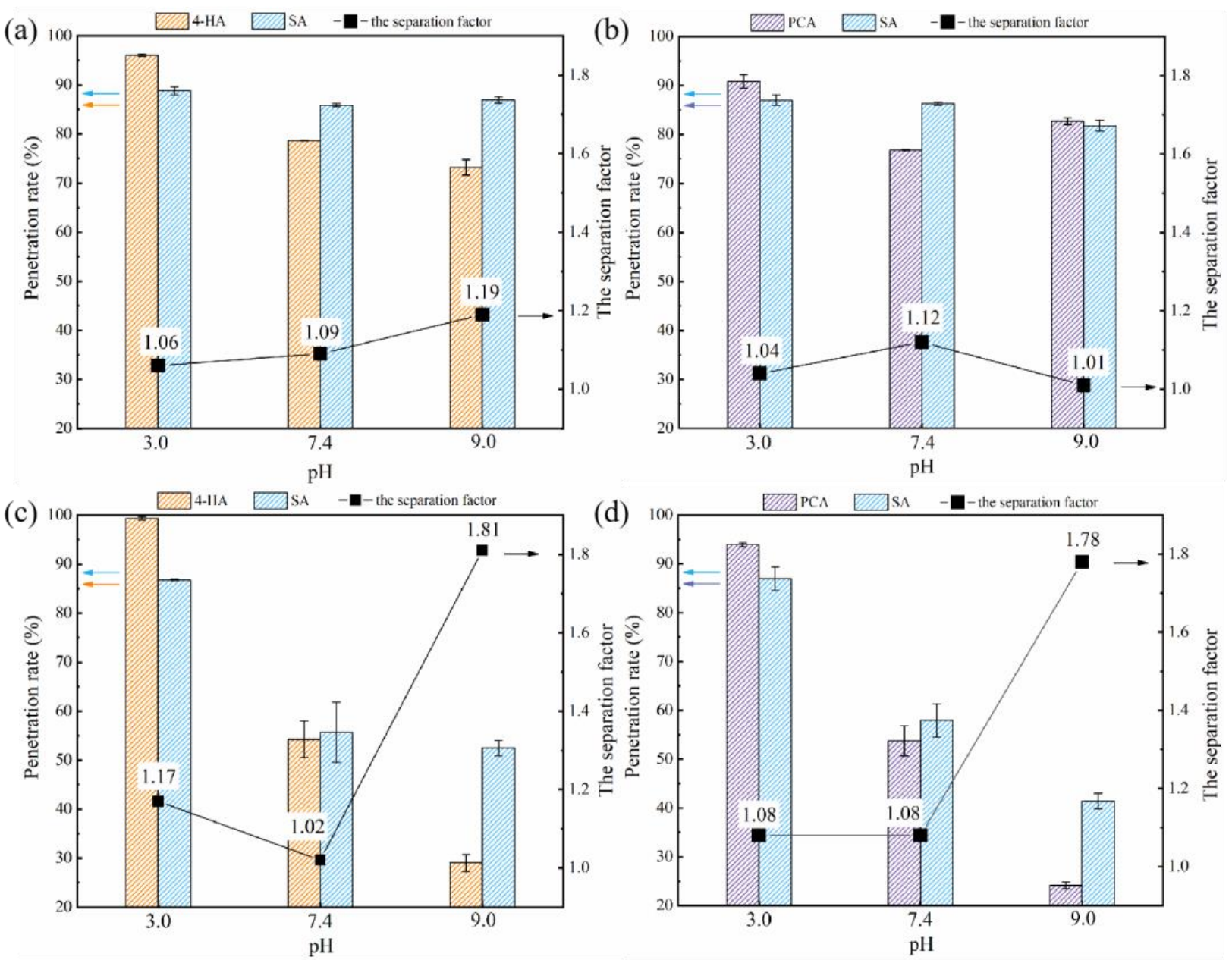

Figure 15. Effect of $\mathrm{pH}$ on the penetration rates of 4-HA+SA and PCA+SA for the two membranes $((\mathbf{a}, \mathbf{b})$, for RC membrane; $(\mathbf{c}, \mathbf{d})$, for PA membrane). The separation factor was calculated by Equation (4).

\section{Conclusions}

This study analyzed the penetration mechanisms of structurally similar phenolic (i.e., benzoic) acids through polyamide (PA) and regenerated cellulose (RC) ultrafiltration membranes, focusing on the electrostatic and hydrophobic effects. Variation of the feed solution $\mathrm{pH}$ significantly affected the observed penetration rates of phenolic acids. Further more, negatively charged, structurally similar phenolic acids can be separated by $\mathrm{pH}$ adjustment using commercial ultrafiltration membranes. For example, the penetration of PCA through the PA membrane decreased from $97 \%$ at $\mathrm{pH} 3.0$, to $22 \%$ at $\mathrm{pH} 9.0$. In addition, the PA membrane produced a superior separation of SA/4-HA and SA/PCA mixtures, with separation factors of 1.81 and 1.78 , respectively. These findings facilitate a deeper understanding of the penetration mechanism of some typical phenolic acids, and may provide a facile method for the separation of phenolic acids and guidance for improving membrane materials.

Supplementary Materials: The following are available online at https:/ /www.mdpi.com/article/10 $.3390 /$ membranes12030285/s1, Figure S1: Pure water flux before and after the adsorption of phenolic acids on the two membranes ( $a$ for GA, b for PCA, c for 4-HA, d for 3-HA). Experimental conditions: 2 bar, feed concentration $=10 \mathrm{mM}$ and $25 \pm 2{ }^{\circ} \mathrm{C}$, Figure S2: Effect of SA concentration on the permeate flux (a for RC membrane, $\mathrm{b}$ for PA membrane). TMP 2 bar, feed concentration 1, 5, $10 \mathrm{mM}$, temperature $25 \pm 2{ }^{\circ} \mathrm{C}$, Figure S3: The correlations between the interfacial energies for RC and PA membrane and the $\log \mathrm{D}$ values of different phenolic acids. feed concentration $10 \mathrm{mM}$, Figure S4: 
Effect of other phenolic acids concentration on the penetration for these two membranes ( $a$ for GA, $b$ for PCA, c for 4-HA, d for 3-HA). Experimental conditions: 2 bar, feed concentration =1, 5, $10 \mathrm{mM}$ and $25 \pm 2{ }^{\circ} \mathrm{C}$, Figure S5: The surface SEM images of the original and SA fouled membranes. (a for original RC membrane, $b$ for original PA membrane), Figure S6: The surface SEM images of the original and fouled membranes. (a for GA fouled RC membrane, $b$ for GA fouled PA membrane, $c$ for PCA fouled RC membrane, $d$ for PCA fouled PA membrane, e for 4-HA fouled RC membrane, $f$ for 4-HA fouled PA membrane, $\mathrm{g}$ for 3-HA fouled RC membrane, $\mathrm{h}$ for 3-HA fouled PA membrane, I for SA fouled RC membrane, J for SA fouled PA membrane), Table S1: The pure water flux loss (\%) of different phenolic acids after filtration and adsorption during RC and PA membrane processes, Table S2: RC and PA membranes contact angles, surface tensions and interfacial energies, Table S3: The penetration of phenolic acids $(1 \mathrm{mM})$ at different $\mathrm{pH}$, Table S4: Roughness of membranes. References [80-92] are cited in the supplementary materials.

Author Contributions: Conceptualization, B.L. and H.Z.; methodology, L.P. and Z.T.; software, H.L.; validation, Q.W. (Qianlian Wu), S.H., Q.L. and M.H.; formal analysis, B.L. and Q.W. (Qinshi Wang); investigation, Q.W. (Qianlian Wu), Y.Z. (Yun Zhang), X.Z., S.H. and Q.L.; resources, H.Z.; data curation, S.H. and Y.Z. (Yun Zhang); writing—original draft preparation, Q.W. (Qinshi Wang) and S.H.; writ-ing-review and editing, B.L.; visualization, Q.W. (Qinshi Wang), Y.Z. (Yun Zhang); supervision, Y.Z. (Yue Zhang); project administration, B.L.; funding acquisition, B.L. and H.Z. All authors have read and agreed to the published version of the manuscript.

Funding: This research was funded by the National Natural Science Foundation of China (Project No. 81773912, 81274096, 81873015, 81673610).

Institutional Review Board Statement: Not applicable.

Informed Consent Statement: Not applicable.

Acknowledgments: This work was supported by the National Natural Science Foundation of China (Project No. 81773912, 81274096, 81873015, 81673610). The authors are grateful to the Nanjing Tech University for their assistance with the SEM and AFM and the Shaanxi University of Chinese Medicine for their help with the contact angle measurements.

Conflicts of Interest: The authors declare there are no conflict of interest regarding the publication of this paper.

\section{References}

1. Fejzić, A.; Ćavar, S. Phenolic Compounds and Antioxidant Activity of Some Citruses. Bull. Chem. Technol. Bosnia Herzeg. 2014, 42, $1-4$.

2. Santos-Buelga, C.; Scalbert, A. Proanthocyanidins and tannin-like compounds-Nature, occurrence, dietary intake and effects on nutrition and health. J. Sci. Food Agric. 2000, 80, 1094-1117. [CrossRef]

3. Jiang, H.; Yang, L.; Xing, X.; Yan, M.; Guo, X.; Yang, B.; Wang, Q.H.; Kuang, H.X. Development of an analytical method for separation of phenolic acids by ultra-performance convergence chromatography (UPC 2 ) using a column packed with a sub-2- $\mu \mathrm{m}$ particle. J. Pharm. Biomed. Anal. 2018, 153, 117-125. [CrossRef]

4. Fernández, M.A.; Sáenz, M.T.; García, M.D. Natural Products: Anti-inflammatory Activity in Rats and Mice of Phenolic Acids Isolated from Scrophularia frutescens. J. Pharm. Pharmacol. 2011, 50, 1183-1186. [CrossRef]

5. Bohm, B.A.; Tryon, R.M. Phenolic compounds in ferns. 1. A survey of some ferns for cinnamic acid and benzoic acid derivatives. Can. J. Bot. 1967, 45, 585-593. [CrossRef]

6. Gomes, C.; Teresa, G.; Andrade, J.L.; Milhazes, N.; Borges, F.; Marques, M. Anticancer activity of phenolic acids of natural or synthetic origin: A structure-activity study. J. Med. Chem. 2003, 46, 5395-5401. [CrossRef]

7. Fernández, M.A.; García, M.D.; Sáenz, M.T. Antibacterial activity of the phenolic acids fractions of Scrophularia frutescens and Scrophularia sambucifolia. J. Ethnopharmacol. 1996, 53, 11-14. [CrossRef]

8. Sroka, Z.; Cisowski, W. Hydrogen peroxide scavenging, antioxidant and anti-radical activity of some phenolic acids. Food Chem. Toxicol. 2003, 41, 753-758. [CrossRef]

9. Jamwal, S.; Dharela, R.; Gupta, R.; Ahn, J.-H.; Chauhan, G.S. Synthesis of crosslinked lipase aggregates and their use in the synthesis of aspirin. Chem. Eng. Res. 2015, 97, 159-164. [CrossRef]

10. Filho, S.F.S.; Pereira, A.C.; Sarraguça, J.M.G.; Sarraguça, M.C.; Lopes, J.; Filho, P.F.F.; Santos, A.O.; Ribeiro, P.R.S. Synthesis of a glibenclamide cocrystal: Full spectroscopic and thermal characterization. J. Pharm. Sci. 2018, 107, 1597-1604. [CrossRef]

11. Mark, R.; Lyu, X.; Lee, J.; Parra-Saldívar, R.; Chen, W.N. Sustainable production of natural phenolics for functional food applications. J. Funct. Foods 2019, 57, 233-254. [CrossRef] 
12. Boumya, W.; Laghrib, F.; Lahrich, S.; Farahi, A.; Achark, M.; Bakasse, M.; Mhammedi, M.A. Electrochemical behavior study of salicylic acid following azo dye formation with 2,4-dinitrophenylhydrazine: Analytical evaluation. South Afr. J. Chem. Eng. 2018, 25, 48-53. [CrossRef]

13. Yüzbaşığlu, E.; Dalyan, E. Salicylic acid alleviates thiram toxicity by modulating antioxidant enzyme capacity and pesticide detoxification systems in the tomato (Solanum lycopersicum Mill.). Plant Physiol. Biochem. 2019, 135, 322-330. [CrossRef]

14. D'Archivio, M.; Scazzocchio, B.; Giovannini, C.; Masella, R. Role of Protocatechuic Acid in Obesity-Related Pathologies. Polyphen. Hum. Health Dis. 2014, 1, 177-189.

15. Elder, D.J.E.; Kelly, D.J. The bacterial degradation of benzoic acid and benzenoid compounds under anaerobic conditions: Unifying trends and new perspectives. FEMS Microbiol. Rev. 1994, 13, 441-468. [CrossRef] [PubMed]

16. Murphy, A.M.; Zhou, T.; Carr, J.P. An update on salicylic acid biosynthesis, its induction and potential exploitation by plant viruses. Curr. Opin. Virol. 2020, 42, 8-17. [CrossRef]

17. Bonnemain, J.L.; Chollet, J.F.; Rocher, F. Transport of salicylic acid and related compounds. In Salicylic Acid; Hayat, S., Ahmad, A., Alyemeni, M., Eds.; Springer: Dordrecht, The Netherlands, 2013; pp. 43-59.

18. U.S. Pharmacopeia. National Formulary; The United States Pharmacopeial Convention: Rockville, MD, USA, 2009.

19. Jonsson, S.; Borén, H. Analysis of mono- and diesters of o-phthalic acid by solid-phase extractions with polystyrenedivinylbenzene-based polymers. J. Chromatogr. A 2002, 963, 393-400. [CrossRef]

20. Kambia, K.; Dine, T.; Gressier, B.; Germe, A.F.; Luyckx, M.; Brunet, C.; Michaud, L.; Gottrand, F. High-performance liquid chromatographic method for the determination of di(2-ethylhexyl) phthalate in total parenteral nutrition and in plasma. $J$. Chromatogr. B Biomed. Sci. Appl. 2001, 755, 297-303. [CrossRef]

21. Han, T.; Zhang, Q.Y.; Zhang, H.; Wen, J.; Wang, Y.; Huang, B.K.; Rahman, K.; Zheng, H.C.; Qin, L.P. Authentication and quantitative analysis on the chemical profile of Xanthium fruit (Cang-Er-Zi) by high-performance liquid chromatography-diodearray detection tandem mass spectrometry method. Anal. Chim. Acta 2009, 634, 272-278. [CrossRef]

22. Wang, Z.; Hwang, S.H.; Huang, B.; Lim, S.S. Identification of tyrosinase specific inhibitors from Xanthium strumarium fruit extract using ultrafiltration-high performance liquid chromatography. J. Chromatogr. B 2015, 1002, 319-328. [CrossRef]

23. Dong, G.; Xu, J.; Gu, Y.; Wei, Y. A general separation method of phenolic acids using pH-zone-refining counter-current chromatography and its application to oat bran. J. Chromatogr. B Anal. Technol. Biomed. Life Sci. 2015, 992, 36-42. [CrossRef] [PubMed]

24. Nevado, J.J.B.; PeñAlvo, G.C.; Robledo, V.R.; Martínez, G.V. New CE-ESI-MS analytical method for the separation, identification and quantification of seven phenolic acids including three isomer compounds in virgin olive oil. Talanta 2009, 79, 1238-1246. [CrossRef] [PubMed]

25. Cartoni, G.; Coccioli, F.; Jasionowska, R. Capillary electrophoretic separation of phenolic acids. J. Chromatogr. A 1995, 709, 209-214. [CrossRef]

26. Nie, L.R.; Lu, J.; Zhang, W.; He, A.; Yao, S. Ionic liquid-modified silica gel as adsorbents for adsorption and separation of water-soluble phenolic acids from Salvia militiorrhiza Bunge. Sep. Purif. Technol. 2015, 155, 2-12. [CrossRef]

27. Neoh, C.H.; Noor, Z.Z.; Mutamim, N.S.A.; Lim, C.K. Green technology in wastewater treatment technologies: Integration of membrane bioreactor with various wastewater treatment systems. Chem. Eng. J. 2016, 283, 582-594. [CrossRef]

28. Anastas, P.; Eghbali, N. Green chemistry: Principles and practice. Chem. Soc. Rev. 2010, 39, 301-312. [CrossRef]

29. Meng, M.J.; Feng, Y.H.; Zhang, M.; Ji, Y.J.; Dai, J.D.; Liu, Y.; Yu, P.; Yan, Y.S. Optimization of surface imprinted layer attached poly(vinylidene fluoride) membrane for selective separation of salicylic acid from acetylsalicylic acid using central composite design. Chem. Eng. J. 2013, 231, 132-145. [CrossRef]

30. Mao, Y.L.; Meng, M.J.; Yan, L.; Sun, F.Q.; Yan, Y.S.; Liu, S.J. Fabrication of highly selective molecularly imprinted membranes for the selective adsorption of methyl salicylate from salicylic acid. Rsc. Adv. 2016, 6, 91659-91668. [CrossRef]

31. Liu, Y.; Meng, M.; Yao, J.; Da, Z.; Li, C. Selective separation of phenol from salicylic acid effluent over molecularly imprinted polystyrene nanospheres composite alumina membranes. Chem. Eng. J. 2016, 286, 622-631. [CrossRef]

32. Yoshikawa, M.; Tanioka, A.; Matsumoto, H. Molecularly imprinted nanofiber membranes. Curr. Opin. Chem. Eng. 2011, 1, 18-26. [CrossRef]

33. Luo, J.Q.; Zeuner, B.; Morthensen, S.T.; Meyer, A.S.; Pinelo, M. Separation of phenolic acids from monosaccharides by low-pressure nanofiltration integrated with laccase pre-treatments. J. Membr. Sci. 2015, 482, 83-91. [CrossRef]

34. Acero, J.L.; Benitez, F.J.; Leal, A.I.; Real, F.J. Removal of phenolic compounds in water by ultrafiltration membrane treatments. J. Environ. Sci. Health Part A Toxic/Hazard. Subst. Environ. Eng. 2005, 40, 1585-1603. [CrossRef] [PubMed]

35. Maiti, S.K.; Thuyavan, Y.L.; Singh, S.; Oberoi, H.S.; Agarwal, G.P. Modeling of the separation of inhibitory components from pretreated rice straw hydrolysate by nanofiltration membranes. Bioresour. Technol. 2012, 114, 419-427. [CrossRef]

36. Ojajuni, O.; Saroj, D.; Cavalli, G. Removal of Organic Micropollutants Using Membrane-Assisted Processes: A Review of Recent Progress. Environ. Technol. Rev. 2015, 4, 17-37. [CrossRef]

37. Bellona, C.; Drewes, J.E.; Xu, P.; Amy, G. Factors affecting the rejection of organic solutes during NF/RO treatment-A literature review. Water Res. 2004, 38, 2795-2809. [CrossRef]

38. Einstein, A. Investigations on the Theory of Brownian Movement; Dover Publications, Inc.: Dover, UK, 1956.

39. Geankoplis, C. Transport Processes and Unit Operations; Allyn Bacon: Boston, MA, USA, 1993. 
40. Shan, J.; Wang, C.; Wei, J.; Tang, C.Y. Rejection of pharmaceuticals by forward osmosis membranes. J. Hazard. Mater. 2012, 227-228, 55-61.

41. Verliefde, A.R.; Heijman, S.G.; Cornelissen, E.R.; Amy, G.; Van der Bruggen, B.; van Dijk, J.C. Influence of electrostatic interactions on the rejection with NF and assessment of the removal efficiency during NF/GAC treatment of pharmaceutically active compounds in surface water. Water Res. 2007, 41, 3227-3240. [CrossRef]

42. Worch, E. Eine neue Gleichung zur Berechnung von Diffusionskoeffizienten gelster Stoffe. Vom. Wasser. 1993, 81, $289-297$.

43. Aziz, M.; Ojumu, T. Exclusion of Estrogenic and Androgenic Steroid Hormones from Municipal Membrane Bioreactor Wastewater Using UF/NF/RO Membranes for Water Reuse Application. Membranes 2020, 10, 37. [CrossRef]

44. Aziz, M.; Kasongo, G. The Removal of Selected Inorganics from Municipal Membrane Bioreactor Wastewater Using UF/NF/RO Membranes for Water Reuse Application: A Pilot-Scale Study. Membranes 2021, 11, 117. [CrossRef]

45. Gai, W.X.; Zhao, D.L.; Chung, T.S. Novel thin film composite hollow fiber membranes incorporated with carbon quantum dots for osmotic power generation. J. Membr. Sci. 2018, 551, 94-102. [CrossRef]

46. Rohani, M.M.; Zydney, A.L. Protein transport through zwitterionic ultrafiltration membranes. J. Membr. Sci. 2012, 397-398, 1-8. [CrossRef]

47. Cheng, J.; Xie, S.; Wang, S.; Xue, Y.; Jiang, L.; Liu, L. Optimization of Protein Removal from Soybean Whey Wastewater Using Chitosan Ultrafiltration. J. Food Process Eng. 2017, 40, 12371-12379. [CrossRef]

48. Lu, X.; Chen, Q.; Lu, J.; Xu, H.; Ji, J. Investigation of reinforced braided hollow fiber membrane containing silver-based butanediol for methyl linolenate separation:Better penetration rate, higher stability. J. Membr. Sci. 2021, 642, 119954. [CrossRef]

49. Cohen, J.; Cohen, P.C.; West, S.G.; Aiken, L.S. Applied Multiple Regression/Correlation Analysis For The Behavioral Sciences; Lawrence Erlbaum Associates: Mahwah, NJ, USA, 2003.

50. Persico, M.; Dhulster, P.; Bazinet, L. Redundancy analysis for determination of the main physicochemical characteristics of filtration membranes explaining their fouling by peptides. J. Membr. Sci. 2018, 563, 708-717. [CrossRef]

51. Mu, S.; Wang, S.; Liang, S.; Xiao, K.; Huang, X. Effect of the Relative Degree of Foulant "Hydrophobicity" on Membrane Fouling J. Membr. Sci. 2019, 570-571, 1-8. [CrossRef]

52. Lin, W.; Li, M.C.; Xiao, K.; Huang, X. The role shifting of organic, inorganic and biological foulants along different positions of a two-stage nanofiltration process. J. Membr. Sci. 2020, 602, 117979. [CrossRef]

53. Comerton, A.M.; Andrews, R.C.; Bagley, D.M.; Yang, P. Membrane adsorption of endocrine disrupting compounds and pharmaceutically active compounds. J. Membr. Sci. 2007, 303, 267-277. [CrossRef]

54. Nghiem, L.D.; Schafer, A.I.; Waite, T.D. Adsorptive interactions between membranes and trace contaminants. Desalination 2002, 147, 269-274. [CrossRef]

55. Han, J.; Qiu, W.; Gao, W. Adsorption of estrone in microfiltration membrane filters. Chem. Eng. J. 2010, 165, 819-826. [CrossRef]

56. Ganiyu, S.O.; Hullebusch, E.D.; Cretin, M.; Esposito, G.; Oturan, M.A. Coupling of membrane filtration and advanced oxidation processes for removal of pharmaceutical residues: A critical review. Sep. Purif. Technol. 2015, 156, 891-914. [CrossRef]

57. Koo, C.H.; Mohammad, A.W.; Suja, F.; Talib, M.Z.M. Review of the effect of selected physicochemical factors on membrane fouling propensity based on fouling indices. Desalination 2012, 287, 167-177. [CrossRef]

58. Licona, K.P.M.; Geaquinto, L.R.D.; Nicolini, J.V.; Figueiredo, N.G.; Chiapetta, S.C.; Habert, A.C.; Yokoyama, L. Assessing potential of nanofiltration and reverse osmosis for removal of toxic pharmaceuticals from water. J. Water Process Eng. 2018, 25, 195-204. [CrossRef]

59. Wray, H.E.; Andrews, R.C.; Bérubé, P.R. Surface shear stress and retention of emerging contaminants during ultrafiltration for drinking water treatment. Sep. Purif. Technol. 2014, 122, 183-191. [CrossRef]

60. Bruggen, B.V.D.; Schaep, J.; Wilms, D. Influence of molecular size, polarity and charge on the retention of organic molecules by nanofiltration. J. Membr. Sci. 1999, 156, 29-41. [CrossRef]

61. Garcia-Ivars, J.; Durá-María, J.; Moscardó-Carreño, C.; Carbonell-Alcaina, C.; Alcaina-Miranda, M.I.; Iborra-Clar, M.I. Rejection of trace pharmaceutically active compounds present in municipal wastewaters using ceramic fine ultrafiltration membranes: Effect of feed solution $\mathrm{pH}$ and fouling phenomena. Sep. Purif. Technol. 2017, 175, 58-71. [CrossRef]

62. Braeken, L.; Ramaekers, R.; Zhang, Y.; Maes, G.; Van der Bruggen, B.; Vandecasteele, C. Influence of hydrophobicity on retention in nanofiltration of aqueous solutions containing organic compounds. J. Membr. Sci. 2005, 252, 195-203. [CrossRef]

63. Azais, A.; Mendret, J.; Petit, E.; Brosillon, S. Evidence of solute-solute interactions and cake enhanced concentration polarization during removal of pharmaceuticals from urban wastewater by nanofiltration. Water Res. 2016, 104, 156-167. [CrossRef]

64. Friedman, M.; Jurgens, H.S. Effect of pH on the stability of plant phenolic compounds. J. Agric. Food Chem. 2000, 48, 2101-2110. [CrossRef]

65. Wolters, J.; Tagliavini, M.; Schafer, A.I. Removal of steroid hormone micropollutants by UF-PBSAC composite in presence of organic matter. J. Membr. Sci. 2019, 592, 117315. [CrossRef]

66. Bódalo, A.; Gómez, E.; Hidalgo, A.M.; Gómez, M.; Murcia, M.D.; López, I. Nanofiltration membranes to reduce phenol concentration in wastewater. Desalination 2009, 245, 680-686. [CrossRef]

67. Catalán, J.; Fernández-Alonso, J. A theoretical study of the stereochemistry of the intramolecular hydrogen bond of salicylic acid. J. Mol. Struct. 1975, 27, 59-65. [CrossRef] 
68. Paul, B.K.; Guchhait, N. Geometrical criteria versus quantum chemical criteria for assessment of intramolecular hydrogen bond (IMHB) interaction: A computational comparison into the effect of chlorine substitution on IMHB of salicylic acid in its lowest energy ground state conform. Chem. Phys. 2013, 412, 58-67. [CrossRef]

69. Hu, J.Y.; Jin, X.; Ong, S.L. Rejection of estrone by nanofiltration: Influence of solution chemistry. J. Membr. Sci. 2007, 302, 188-196. [CrossRef]

70. Moons, K.; Van der Bruggen, B. Removal of micropollutants during drinking water production from surface water with nanofiltration. Desalination 2006, 199, 245-247. [CrossRef]

71. Taheran, M.; Brar, S.K.; Verma, M.; Surampalli, R.Y.; Zhang, T.C.; Valero, J.R. Membrane processes for removal of pharmaceutically active compounds (PhACs) from water and wastewaters. Sci. Total Environ. 2016, 547, 60-77. [CrossRef]

72. Verliefde, A.; Cornelissen, E.; Amy, G.; Van der Bruggen, B.; van Dijk, H. Priority organic micropollutants in water sources in Flanders and the Netherlands and assessment of removal possibilities with nanofiltration. Environ. Pollut. 2007, 146, 281-289. [CrossRef]

73. Yoon, Y.; Westerhoff, P.; Snyder, S.A.; Wert, E.C.; Yoon, J. Removal of endocrine disrupting compounds and pharmaceuticals by nanofiltration and ultrafiltration membranes. Desalination 2007, 202, 16-23. [CrossRef]

74. Kiso, Y.; Sugiura, Y.; Kitao, T.; Nishimura, K. Effects of hydrophobicity and molecular size on rejection of aromatic pesticides with nanofiltration membranes. J. Membr. Sci. 2001, 192, 1-10. [CrossRef]

75. Han, J.; Qiu, W.; Hu, J.Y.; Gao, W. Chemisorption of estrone in nylon microfiltration membranes: Adsorption mechanism and potential use for estrone removal from water. Water Res. 2012, 46, 873-881. [CrossRef]

76. Liu, Y.L.; Wang, X.M.; Yang, H.W.; Xie, Y.F.F. Quantifying the influence of solute-membrane interactions on adsorption and rejection of pharmaceuticals by NF/RO membranes. J. Membr. Sci. 2018, 551, 37-46. [CrossRef]

77. Ismail, N.H.; Salleh, W.; Ismail, A.F.; Hasbullah, H.; Jaafar, J. Hydrophilic polymer-based membrane for oily wastewater treatment: A review. Sep. Purif. Technol. 2019, 233, 116007. [CrossRef]

78. Sun, H.; Zhang, Y.; Sadam, H.; Ma, J.; Bai, Y.; Shen, X.; Kim, J.K.; Shao, L. Novel mussel-inspired zwitterionic hydrophilic polymer to boost membrane water-treatment performance. J. Membr. Sci. 2019, 582, 1-8. [CrossRef]

79. Lv, J.; Zhang, G.; Zhang, H.; Zhao, C.; Yang, F. Improvement of antifouling performances for modified PVDF ultrafiltration membrane with hydrophilic cellulose nanocrystal. Appl. Surf. Sci. 2018, 440, 1091-1100. [CrossRef]

80. Cai, M.; Hou, W.Z.; Lv, Y.Q.; Sun, P.L. Behavior and rejection mechanisms of fruit juice phenolic compounds in model solution during nanofiltration. J. Food Eng. 2017, 195, 97-104. [CrossRef]

81. Wang, J.; Mo, Y.; Mahendra, S.; Hoek, E.M.V. Effects of water chemistry on structure and performance of polyamide composite membranes. J Membr. Sci. 2014, 452, 415-425. [CrossRef]

82. Oss, C.J. Development and applications of the interfacial tension between water and organic or biological surfaces. Colloids Surf. B Biointerfaces 2007, 54, 2-9.

83. Liang, S.; Kang, Y.; Tiraferri, A.; Giannelis, E.P.; Huang, X.; Elimelech, M. Highly hydrophilic polyvinylidene fluoride (PVDF) ultrafiltration membranes via postfabrication grafting of surface-tailored silica nanoparticles. ACS Appl. Mater. Interfaces 2013, 5, 6694-6703. [CrossRef]

84. Bellona, C.; Marts, M.; Drewes, J.E. The effect of organic membrane fouling on the properties and rejection characteristics of nanofiltration membranes. Sep. Purif. Technol. 2010, 74, 44-54. [CrossRef]

85. Plakas, K.V.; Karabelas, A.J. A systematic study on triazine retention by fouled with humic substances NF/ULPRO membranes. Sep. Purif. Technol. 2011, 80, 246-261. [CrossRef]

86. Subhi, N.; Verliefde, A.R.D.; Chen, V.; Le-Clech, P. Assessment of physicochemical interactions in hollow fibre ultrafiltration membrane by contact angle analysis. J. Membr. Sci. 2012, 403, 32-40. [CrossRef]

87. Ahmad, A.L.; Yasin, N.H.M.; Derek, C.J.C.; Lim, J.K. Harvesting of microalgal biomass using MF membrane: Kinetic model, CDE model and extended DLVO theory. J. Membr. Sci. 2013, 446, 341-349. [CrossRef]

88. Gao, F.; Wang, J.; Zhang, H.W.; Hang, M.Q.A.; Cui, Z.; Yang, G. Interaction energy and competitive adsorption evaluation of different NOM fractions on aged membrane surfaces. J. Membr. Sci. 2017, 542, 195-207. [CrossRef]

89. Oss, C.J.V. Interfacial Forces in Aqueous Media; Marcel Dekker Inc.: New York, NY, USA, 1994; pp. $209-210$.

90. Jin, X.; Huang, X.; Hoek, E.M. Role of specific ion interactions in seawater RO membrane fouling by alginic acid. Environ. Sci. Technol. 2009, 43, 3580-3587. [CrossRef]

91. Hurwitz, G.; Guillen, G.R.; Hoek, E.M.V. Probing polyamide membrane surface charge, zeta potential, wettability, and hydrophilicity with contact angle measurements. J. Membr. Sci. 2010, 349, 349-357. [CrossRef]

92. Luo, J.Q.; Ding, L.H.; Wan, Y.H.; Paullier, P.; Jaffrin, M.Y. Application of NF-RDM (nanofiltration rotating disk membrane) module under extreme hydraulic conditions for the treatment of dairy wastewater. Chem. Eng. J. 2010, 163, 307-316. [CrossRef] 